Cochrane Database of Systematic Reviews

\title{
Gamma aminobutyric acid (GABA) receptor agonists for acute stroke
} (Review)

Liu J, Zhang J, Wang LN

Liu J, Zhang J, Wang LN.

Gamma aminobutyric acid (GABA) receptor agonists for acute stroke.

Cochrane Database of Systematic Reviews 2018, Issue 10. Art. No.: CD009622.

DOI: 10.1002/14651858.CD009622.pub5.

www.cochranelibrary.com 
TABLE OF CONTENTS

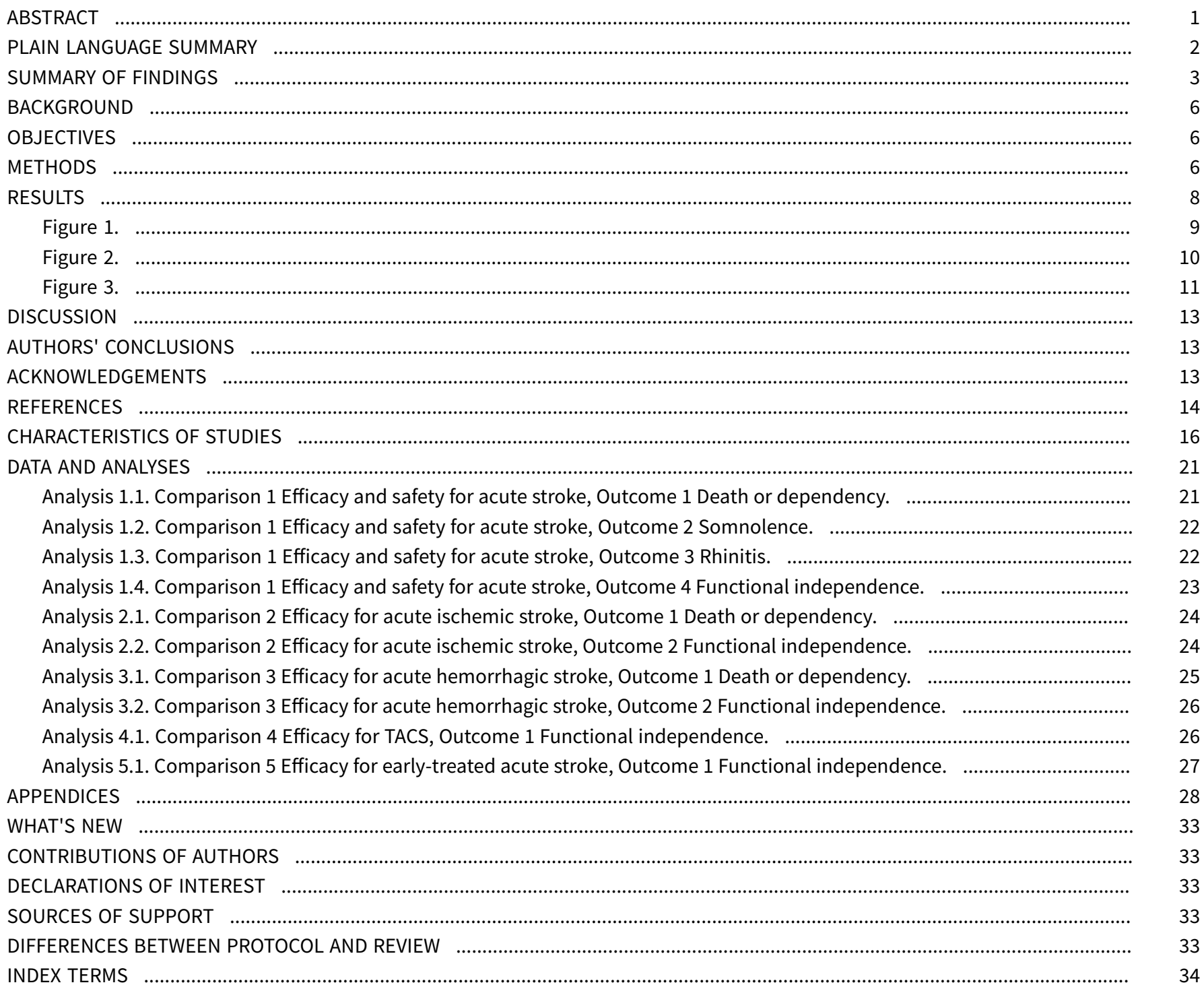


[Intervention Review]

\section{Gamma aminobutyric acid (GABA) receptor agonists for acute stroke}

Jia Liu1a, Jing Zhang1b, Lu-Ning Wang2

1Department of Neurology, Xuanwu Hospital, Capital Medical University, Beijing, China. 2Department of Geriatric Neurology, Chinese PLA General Hospital, Beijing, China

${ }^{a}$ Co-first author. ${ }^{b}$ Co-first author

Contact: Lu-Ning Wang, Department of Geriatric Neurology, Chinese PLA General Hospital, Fuxing Road 28, Haidian District, Beijing, 100853, China. In_wang301@sohu.com.

Editorial group: Cochrane Stroke Group.

Publication status and date: New search for studies and content updated (no change to conclusions), published in Issue 10, 2018.

Citation: Liu J, Zhang J, Wang LN. Gamma aminobutyric acid (GABA) receptor agonists for acute stroke. Cochrane Database of Systematic Reviews 2018, Issue 10. Art. No.: CD009622. DOI: 10.1002/14651858.CD009622.pub5.

Copyright @ 2018 The Cochrane Collaboration. Published by John Wiley \& Sons, Ltd.

\section{A B S T R A C T}

\section{Background}

Gamma aminobutyric acid (GABA) receptor agonists have been shown to have a neuroprotectant effect in reducing infarct size and improving functional outcome in animal models of cerebrovascular disease. However, the sedative effects of GABA receptor agonists have limited their wider application in people with acute stroke, due to the potential risk of stupor. This is an update of a Cochrane Review first published in 2013, and previously updated in 2014 and 2016.

\section{Objectives}

To determine the efficacy and safety of GABA receptor agonists in the treatment of acute stroke.

\section{Search methods}

We searched the Cochrane Stroke Group Trials Register (accessed May 2018), the Cochrane Central Register of Controlled Trials (CENTRAL) 2018, Issue 4 (accessed May 2018), MEDLINE (from 1949 to May 2018), Embase (from 1980 to May 2018), CINAHL (from 1982 to May 2018), AMED (from 1985 to May 2018), and 11 Chinese databases (accessed May 2018). In an effort to identify further published, unpublished, and ongoing trials we searched ongoing trial registers, reference lists, and relevant conference proceedings, and contacted authors and pharmaceutical companies.

\section{Selection criteria}

We included randomized controlled trials (RCTs) investigating GABA receptor agonists versus placebo for people with acute stroke (within 12 hours after stroke onset), with the primary outcomes of efficacy and safety.

\section{Data collection and analysis}

Two review authors independently screened the titles and abstracts of identified records, selected studies for inclusion, extracted eligible data, cross-checked the data for accuracy, and assessed the risk of bias. We used the GRADE approach to assess the quality of the evidence.

\section{Main results}

We included five trials with 3838 participants (acute ischemic or hemorrhagic stroke patients, 3758 analyzed). Most of the participants recruited had acute ischaemic stroke, with limited data available from participants with other stroke subtypes, including total anterior circulation syndrome (TACS). The methodological quality of the included trials was generally good, with an unclear risk for selection bias only. For death and dependency at three months, pooled results did not find a significant difference for chlormethiazole versus placebo (risk ratio (RR) 1.03, 95\% confidence interval (CI) 0.96 to 1.11; four trials; 2909 participants; moderate-quality evidence) and for diazepam versus placebo (RR $0.94,95 \% \mathrm{Cl} 0.82$ to 1.07 ; one trial; 849 participants; moderate-quality evidence). The most frequent adverse events 
related to chlormethiazole were somnolence (RR 4.56, 95\% Cl 3.50 to 5.95; two trials; 2527 participants; moderate-quality evidence) and rhinitis (RR 4.75, 95\% Cl 2.67 to 8.46; two trials; 2527 participants; moderate-quality evidence).

\section{Authors' conclusions}

This review provides moderate-quality evidence that fails to support the use of GABA receptor agonists (chlormethiazole or diazepam) for the treatment of people with acute stroke. More well-designed RCTs with large samples of participants with total anterior circulation syndrome are required to determine if there are benefits for this subgroup. Somnolence and rhinitis are frequent adverse events related to chlormethiazole.

\section{PLAIN LANGUAGE SUMMARY}

\section{Gamma aminobutyric acid (GABA) receptor agonists for acute stroke}

Question: Are GABA receptor agonist drugs effective and safe in the treatment of acute stroke?

Background: GABA receptor agonists are a type of drug that may help protect the brain in acute stroke. This group of drugs, which includes diazepam and chlormethiazole, has been used as traditional sedatives for several decades, and have been found to be beneficial in stroke studies in animals. However, the sedative effect of GABA receptor agonists could be harmful for people with acute stroke.

Study characteristics: We identified five studies to May 2018 that met our inclusion criteria; they randomized 3838 participants (acute ischemic or hemorrhagic stroke patients) and analyzed 3758. The quality of all the studies was generally good, with a low risk of bias. One study tested the effects and safety of diazepam for acute stroke in 849 participants within 12 hours of stroke onset. Four studies tested the effects and safety of chlormethiazole in 2909 participants with acute stroke, within 12 hours of stroke onset; 95 participants had stroke caused by bleeding and were analyzed separately.

Key results: All five trials reported death and dependency at three months. There was no significant difference between the chlormethiazole and placebo groups or between the diazepam and placebo groups. The most frequent side effects caused by chlormethiazole were drowsiness and nasal irritation.

Quality of the evidence: In conclusion, moderate-quality evidence did not support the use of GABA receptor agonists for the treatment of people with acute stroke. 


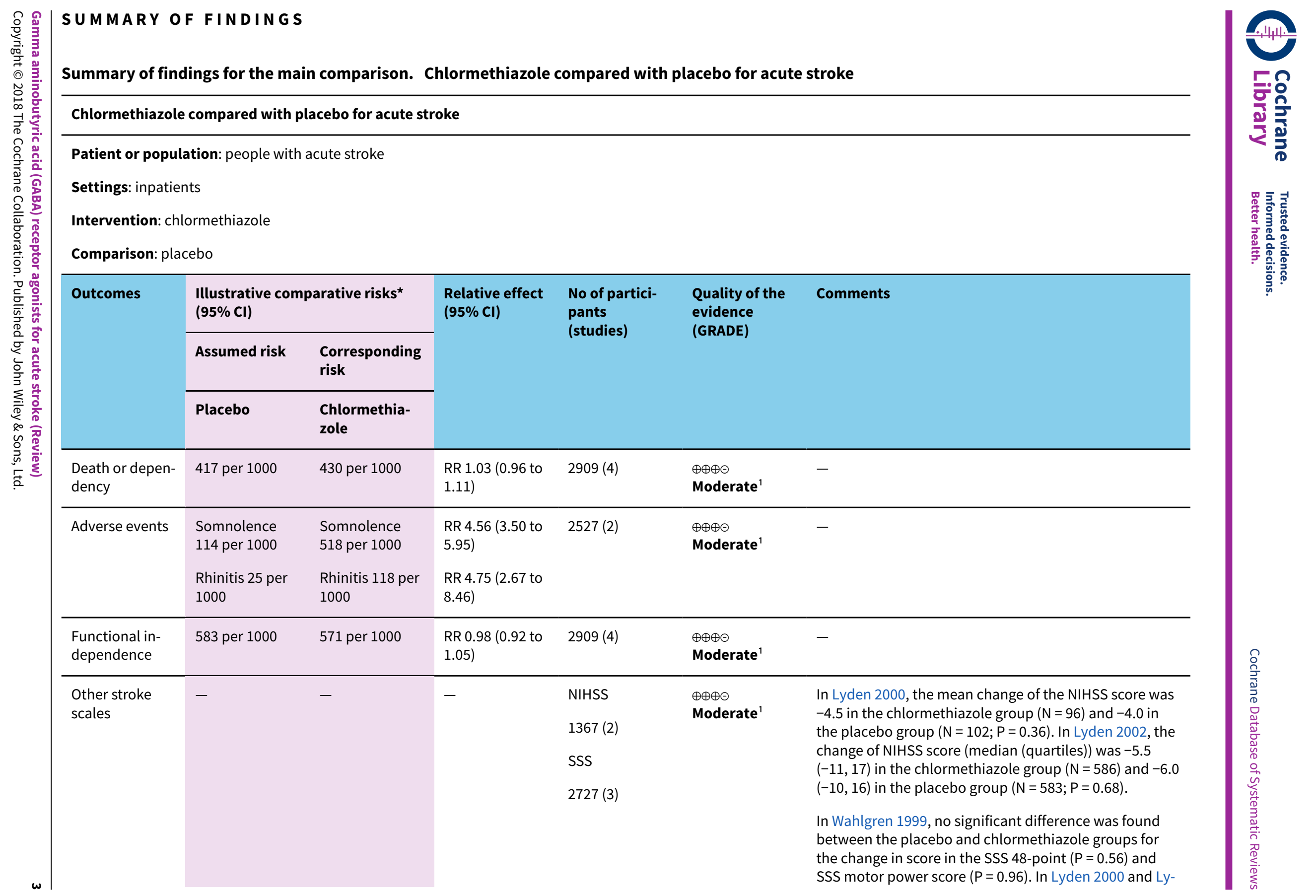




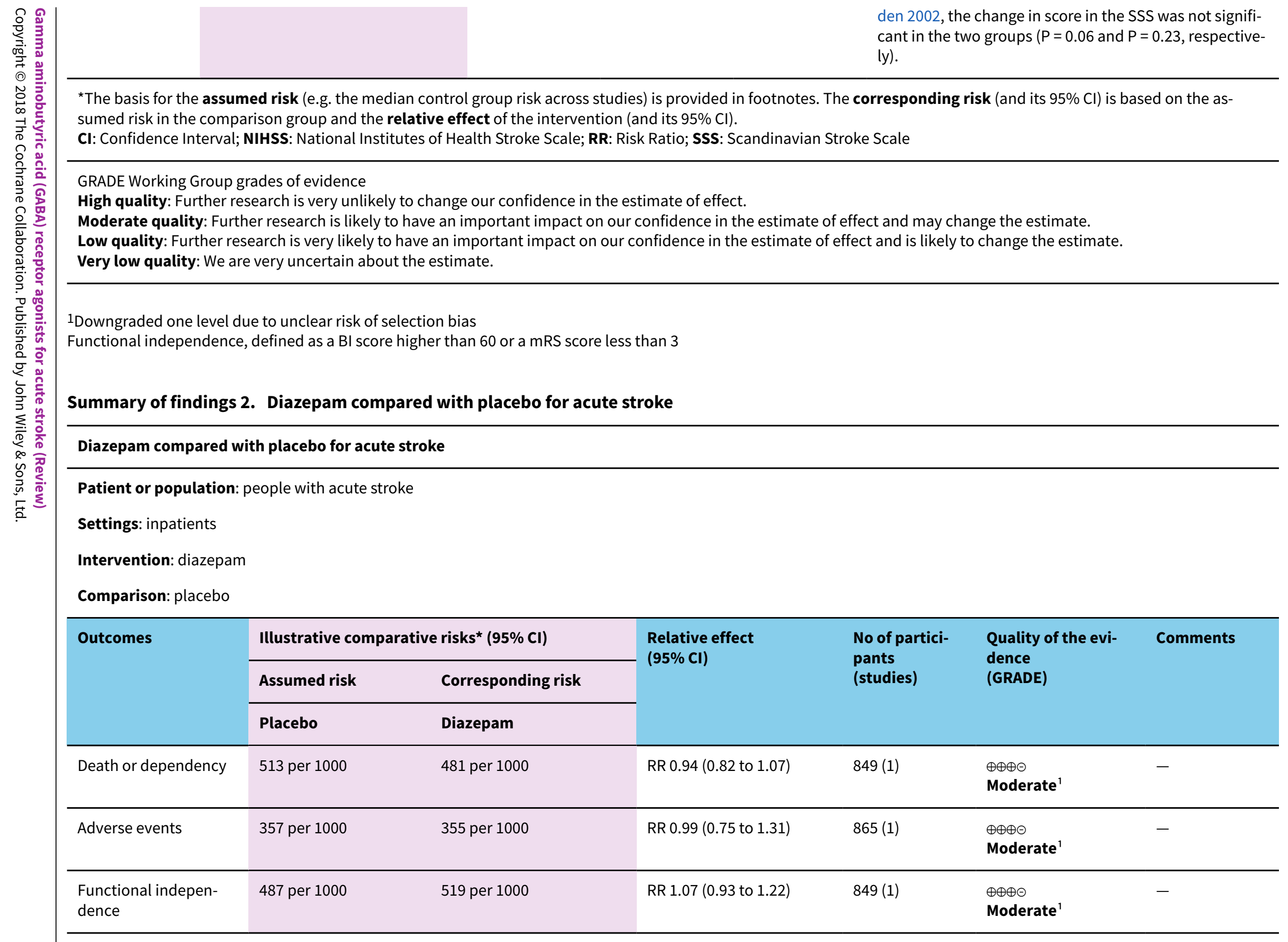


${ }^{*}$ The basis for the assumed risk (e.g. the median control group risk across studies) is provided in footnotes. The corresponding risk (and its $95 \% \mathrm{Cl}$ ) is based on the assumed risk in the comparison group and the relative effect of the intervention (and its $95 \% \mathrm{CI}$ ).

Cl: Confidence interval; RR: Risk Ratio

GRADE Working Group grades of evidence

High quality: Further research is very unlikely to change our confidence in the estimate of effect.

Moderate quality: Further research is likely to have an important impact on our confidence in the estimate of effect and may change the estimate.

Low quality: Further research is very likely to have an important impact on our confidence in the estimate of effect and is likely to change the estimate.

Very low quality: We are very uncertain about the estimate.

1Downgraded one level: one study with small sample size

Functional independence, defined as a BI score higher than 60 or a mRS score less than 3 


\section{B A C K G R O U N D}

\section{Description of the condition}

Acute stroke is defined as a clinical syndrome of sudden onset of focal or global disturbance of central nervous system function, due to an interruption of the cerebral circulation (Warlow 2001). Ischemic stroke is the most frequent type ( $80 \%$ of all strokes), followed by intracerebral hemorrhage (15\%) and subarachnoid hemorrhage (5\%). The estimated annual incidence of stroke is $0.25 \%$, and increases with age (Simon 2009; WHO 2011). Twothirds of all strokes occur in those older than 65 years (AHA 2002). The common risk factors include smoking, hypertension, diabetes, carotid stenosis, hypercholesterolemia, hyperhomocysteinemia, alcohol abuse, and a high-fat diet (Cruz-Flores 2011). The prognosis is poor, with one-third of patients dying and one-third left with permanent disability (WHO 2011). In addition, stroke is a costly condition that incurs treatment, ongoing care, and indirect costs (Saka 2009).

\section{Description of the intervention}

Neuroprotective agents have attracted a lot of attention for the treatment of acute stroke, and are expected to be helpful in protecting vulnerable neurons and salvaging the ischemic penumbra (ischemic but still viable tissue). The most common neuroprotectants include excitatory amino acid antagonists, gangliosides, calcium channel antagonists, lubeluzole, methylxanthine derivatives, and tirilazad - each with different modes of action. It is disappointing that none of these treatments has been confirmed to be effective in the acute phase of stroke (Bath 2001; Bath 2004; Candelise 2001; Gandolfo 2002; Horn 2000; Muir 2003). Therefore, it is necessary to examine other potential neuroprotectants for stroke. Gamma aminobutyric acid (GABA) receptor agonists (e.g. diazepam and chlormethiazole) are traditional sedatives that have been used for several decades. They have also been found to be effective in reducing infarct size in histology, and improving functional outcome in animal models of cerebral ischemia (Gasior 2004; Marshall 2003; Sydserff 2002).

\section{How the intervention might work}

GABA is the main inhibitory neurotransmitter in the central nervous system and acts by reducing depolarization-induced and ischemiainduced glutamate release (Nelson 2000; Vaishnav 2002). Firstly, GABA can trigger hyperpolarization of neurons through anion channels (GABAA) and presynaptic G-protein coupled receptors (GABAB) (Wilby 2004). This hyperpolarization counteracts the depolarization, which is the initiating event in the biochemical ischemic cascade (Tuttolomondo 2009). Secondly, there is no shortage of GABA in ischemic conditions, but the affinity of GABA receptors is decreased (Alicke 1995). Activation of GABA reduces respiratory rate, preserving glucose and reducing acidosis, which facilitates local cerebral blood flow (Chi 2011; Zubcevic 2010). Finally, GABA receptor agonists can induce hypothermia, which is also regarded as a neuroprotective condition for acute stroke (Klassman 2011; Visser 2005). In certain conditions, such as total anterior circulation syndrome (TACS), there is particular interest in neuroprotectants, because the large volume of infarction may suggest a large penumbra as a target for therapy.

\section{Why it is important to do this review}

There are existing clinical trials on the effects of GABA receptor agonists in acute stroke based on the results of preclinical in vivo studies. However, conflicting results limit their wider application in sedation caused by GABA receptor agonists in acute stroke with edema (Hanna 1996). This is an update of a Cochrane Review first published in 2013 (Liu 2013), and previously updated in 2014 and 2016 (Liu 2014; Liu 2016), to evaluate the efficacy and safety of GABA receptor agonists through high-quality randomized controlled trials (RCTs).

\section{O B J E C T IVES}

To determine the efficacy and safety of GABA receptor agonists in the treatment of acute stroke.

\section{METHODS}

\section{Criteria for considering studies for this review Types of studies}

All randomized controlled trials (RCTs) investigating GABA receptor agonists for people with acute stroke were eligible. We excluded uncontrolled, non-randomized, or quasi-randomized trials.

\section{Types of participants}

We included people who had suffered an acute stroke within the previous 12 hours. There were no limitations in gender, age, or subtype of stroke.

\section{Types of interventions}

- Intervention: GABA receptor agonists administered orally or intravenously, regardless of length of treatment or dosage of treatment.

- Comparator: placebo.

We considered interventions with concomitant therapies when they were administered in both treatment arms.

\section{Types of outcome measures}

We assessed the following outcomes, measured at three-month follow-up.

\section{Primary outcomes}

\section{Efficacy}

Death or dependency at the end of follow-up (at least three months). We defined dependency as a Barthel Index (BI) score of 60 or less, or the modified Rankin Scale (mRS) Grades 3 to 5 (Sulter 1999), or we used the definition provided by the researchers.

\section{Safety}

The number of people with adverse events (serious adverse events and frequent adverse events, e.g. somnolence and rhinitis).

\section{Secondary outcomes}

Functional independence

Defined as a BI score greater than 60 , or a mRS less than 3 . 


\section{Neurological function}

Measured by other stroke scales, e.g. National Institutes of Health Stroke Scale (NIHSS) or Scandinavian Stroke Scale (SSS).

\section{Search methods for identification of studies}

See the Cochrane Stroke Group's search methods. We searched for trials in all languages and arranged translation of relevant papers published in languages other than English.

\section{Electronic searches}

We searched the Cochrane Stroke Group Trials Register (May 2018) and the following electronic bibliographic databases.

- Cochrane Central Register of Controlled Trials (CENTRAL; 2018, Issue 4), in the Cochrane Library (accessed 22 May 2018; Appendix 1).

- MEDLINE Ovid (from 1949 to 22 May 2018; Appendix 2).

- Embase Ovid (from 1980 to 22 May 2018; Appendix 3).

- CINAHL EBSCO (Cumulative Index to Nursing and Allied Health Literature; from 1982 to 22 May 2018; Appendix 4).

- AMED Ovid (Allied and Complementary Medicine Database; from 1985 to 22 May 2018; Appendix 5).

We searched the following Chinese databases with the equivalent search strategy (Appendix 6).

- CBM-disc (China Biological Medicine Databases; from 1979 to 22 May 2018).

- Chinese Science and Technique Journals Database (VIP; from 1989 to 22 May 2018).

- CNKI (China National Knowledge Infrastructure; from 1979 to 22 May 2018).

- Chinese MD and DD Dissertations in CNKI (accessed 22 May 2018).

- CACP (Chinese Academic Conference Papers Database; from 1998 to 22 May 2018)

- CDDB (Chinese Dissertations Database; from 1977 to 22 May 2018).

- Chinese Evidence-Based Medicine Database (accessed 22 May 2018).

- CMAC (China Medical Academic Conferences; from 1994 to 22 May 2018).

- CMCC (Chinese Medical Current Contents; from 1994 to 22 May 2018).

- Wanfang Data (www.wanfangdata.com) (from 1984 to 22 May 2018).

We developed the MEDLINE search strategy with the help of the Cochrane Stroke Group Information Specialist and adapted it for the other databases.

To identify further published, unpublished, and ongoing trials, we searched the following trials registers in May 2018 (Appendix 7).

- ClinicalTrials.gov (www.clinicaltrials.gov).

- EU Clinical Trials Register (www.clinicaltrialsregister.eu).

- Stroke Trials Registry (www.strokecenter.org/trials/).

- ISRCTN registry (www.isrctn.com).
- WHO International Clinical Trials Registry Platform (apps.who.int/trialsearch/).

- Chinese Clinical Trial Registry, ChiCTR (www.chictr.org).

\section{Searching other resources}

We also:

- used Science Citation Index Cited Reference Search for forward tracking of important articles;

- searched reference lists of reviews and retrieved articles;

- searched conference proceedings, including those of the 25 th, 26th and 27th European Stroke Conference (2016, 2017 and 2018) and the 8th, 9th and 10th World Stroke Congress (2012, 2014 and 2016);

- contacted authors for missing information, where necessary;

- contacted the manufacturer (AstraZeneca pharmaceutical company) for updated information.

\section{Data collection and analysis}

\section{Selection of studies}

Two review authors (JL, LW) independently screened titles and abstracts of the citations produced by the database searches and excluded obviously irrelevant studies. We obtained the fulltext articles of all remaining citations and the same two authors independently selected studies that met the inclusion criteria. Both authors independently evaluated eligibility and assessed the risk of bias (methodological quality) of these studies. We resolved any disagreements by discussion, or referred them to an independent person if necessary.

\section{Data extraction and management}

Two review authors (JL, LW) independently extracted eligible data from the published reports onto pre-standardized forms, and cross-checked them for accuracy. We used checklists to independently record relevant details including methods of generating the randomization schedule, method of concealment of allocation, blinding of assessors, intention-to-treat analysis, adverse events and dropouts for all reasons, important imbalance in prognostic factors, participants (socio-demographic and related clinical information), interventions (medications and non-pharmacological interventions), and outcomes. We resolved disagreements by discussion.

\section{Assessment of risk of bias in included studies}

Two review authors (JL, LW) independently assessed the risk of bias for each study using the criteria outlined in the Cochrane Handbook for Systematic Reviews of Interventions (Higgins 2011). We resolved any disagreements by discussion between ourselves. We assessed the risk of bias according to the following domains.

- Random sequence generation.

- Allocation concealment.

- Blinding of participants and personnel.

- Blinding of outcome assessment.

- Incomplete outcome data.

- Selective outcome reporting.

- Other bias. 
We assessed the risk of bias for each domain as high, low, or unclear risk, and provided information from the study report with the description of the sources of bias. We judged a study to be at low risk of bias if all key domains were rated at low risk of bias. If one or more of the domains was rated at unclear risk of bias, we judged the study to be at unclear risk of bias. We judged the study to be at high risk of bias if one or more of the domains was rated at high risk of bias.

\section{Measures of treatment effect}

We expressed results for dichotomous outcomes as risk ratios (RR) with $95 \%$ confidence intervals $(\mathrm{Cl})$. We entered and analyzed data in Review Manager 5 (RevMan 5) (Review Manager 2014).

\section{Unit of analysis issues}

We dealt with any unit of analysis issues according to guidance in the Cochrane Handbook for Systematic Reviews of Interventions (Higgins 2011).

\section{Dealing with missing data}

We attempted to contact the authors of the studies for further details if any data were missing, and to establish the characteristics of unpublished trials, through correspondence with trial coordinators or principal investigators.

\section{Assessment of heterogeneity}

We tested heterogeneity using the $\mathrm{I}^{2}$ statistic and made a judgement as to whether significant heterogeneity was present (Higgins 2011). We took $\mathrm{I}^{2}$ values over $50 \%$ as suggestive of substantial heterogeneity. However, the direction and magnitude of effects were taken into account.

\section{Assessment of reporting biases}

We had planned to use the funnel plot method if there were sufficient numbers of trials to allow for a meaningful presentation (Egger 1997).

\section{Data synthesis}

If a sufficient number of comparable studies with a low risk of bias were available, we had planned to carry out meta-analyses. We calculated the overall effects using a random-effects model, regardless of the level of heterogeneity. If substantial heterogeneity between the studies prevented us from combining outcome data, we gave a descriptive summary of the results.

\section{Summary of findings and quality of the evidence (GRADE)}

In a post-hoc change, we have presented two 'Summary of findings' tables, one for each comparison (Summary of findings for the main comparison; Summary of findings 2). We reported all outcomes in the tables.

We determined the quality of the evidence using the GRADE approach, and downgraded evidence in the presence of a high or unclear risk of bias in at least one study, indirectness of the evidence, unexplained heterogeneity or inconsistency, imprecision of results, or a high probability of publication bias. We downgraded evidence by one level if we considered the limitation to be serious and by two levels if very serious.

\section{Subgroup analysis and investigation of heterogeneity}

We analyzed subgroups of studies categorized by ischemic or hemorrhagic stroke, subtype of stroke (such as total anterior circulation infarcts, partial anterior circulation infarcts, posterior circulation infarcts, and lacunar infarcts), and time from stroke onset to treatment administration.

\section{Sensitivity analysis}

We undertook sensitivity analyses to assess the robustness of results in fixed-effect versus random-effects models, and studies at high risk versus low risk of bias. We also used these sensitivity analyses to examine potential sources of methodological heterogeneity.

\section{RE S U L T S}

\section{Description of studies}

\section{Results of the search}

From our original review, we included five studies. When we re-ran the searches in May 2018, we identified 653 papers after removing duplicates (Figure 1). We acquired and screened the full text of four articles (Agarwal 2017; Chow 2017; Darmani 2016; Nepveu 2017); these studies did not meet the inclusion criteria due to the ineligible participants. Agreement between the review authors on exclusion was $100 \%$. We found no ongoing RCTs. 
Figure 1. Study flow diagram.

5 eligible studies ( 10
articles) identified for
the last version of
review
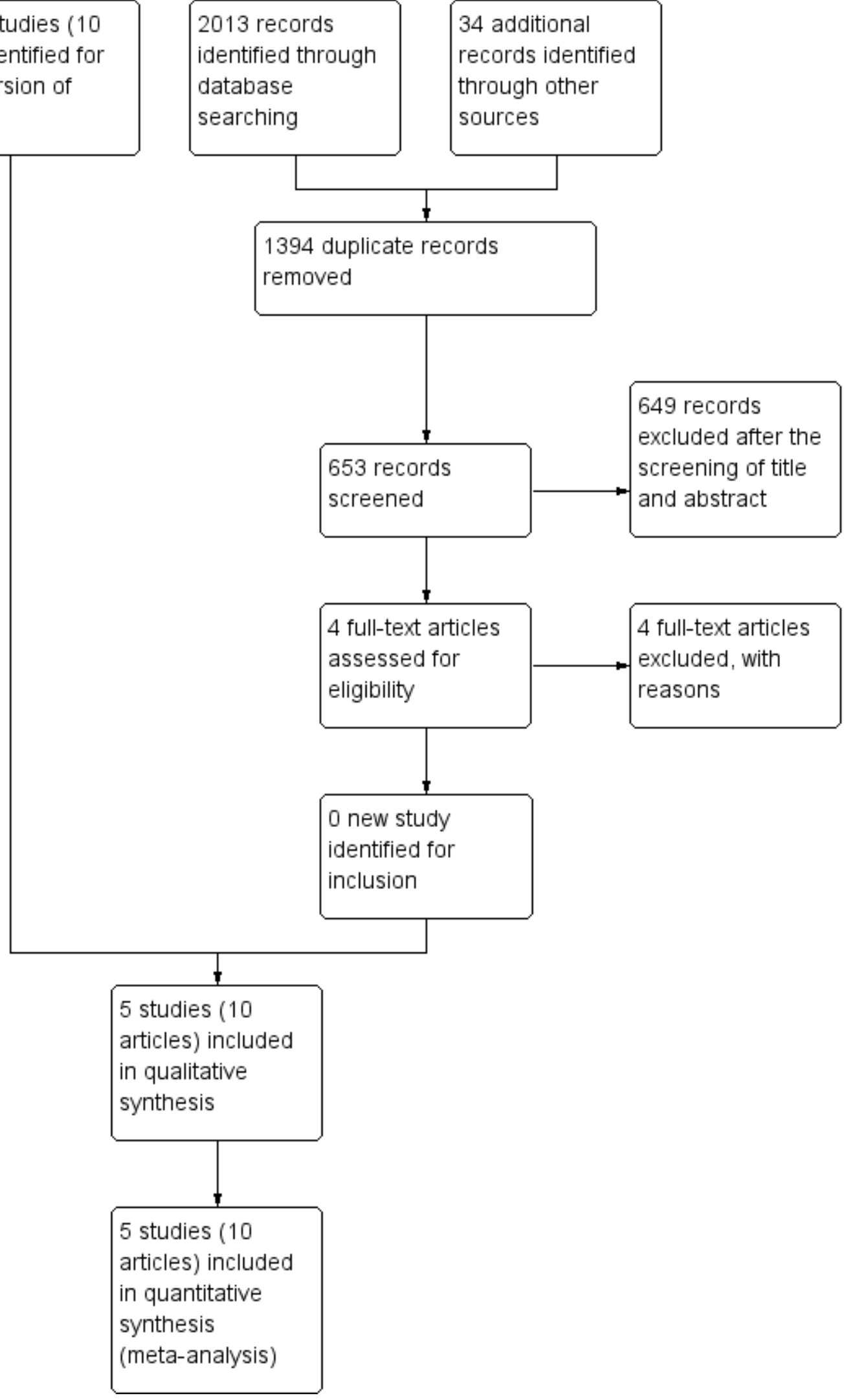


\section{Included studies}

We included five studies, with 3838 participants. One study evaluated the efficacy and safety of diazepam for acute stroke in 879 participants, included within 12 hours of stroke onset (Lodder 2006). The Chlormethiazole Acute Stroke Study focused mainly on the efficacy and safety of chlormethiazole in 1360 participants with acute stroke, included within 12 hours of stroke onset (Wahlgren 1999): 95 participants had hemorrhagic stroke and were analyzed separately. We undertook a subgroup analysis of TACS in 545 participants. After the completion of Wahlgren 1999, another chlormethiazole acute stroke study in ischemic, hemorrhagic and t-PA treated stroke (CLASS-IHT) was designed. All participants were included within 12 hours after stroke onset. There were 201 participants randomized in Lyden 2000, 200 in Lyden 2001, and 1198 in Lyden 2002. We have provided relevant information about the included trials in the Characteristics of included studies table.

\section{Excluded studies}

We excluded 11 studies after full-text evaluation. We have provided the reasons for exclusion in the Characteristics of excluded studies table.

\section{Risk of bias in included studies}

Information regarding risk of bias is provided in Figure 2 and Figure 3.

\section{Figure 2. Risk of bias graph: review authors' judgements about each risk of bias item presented as percentages across all included studies.}

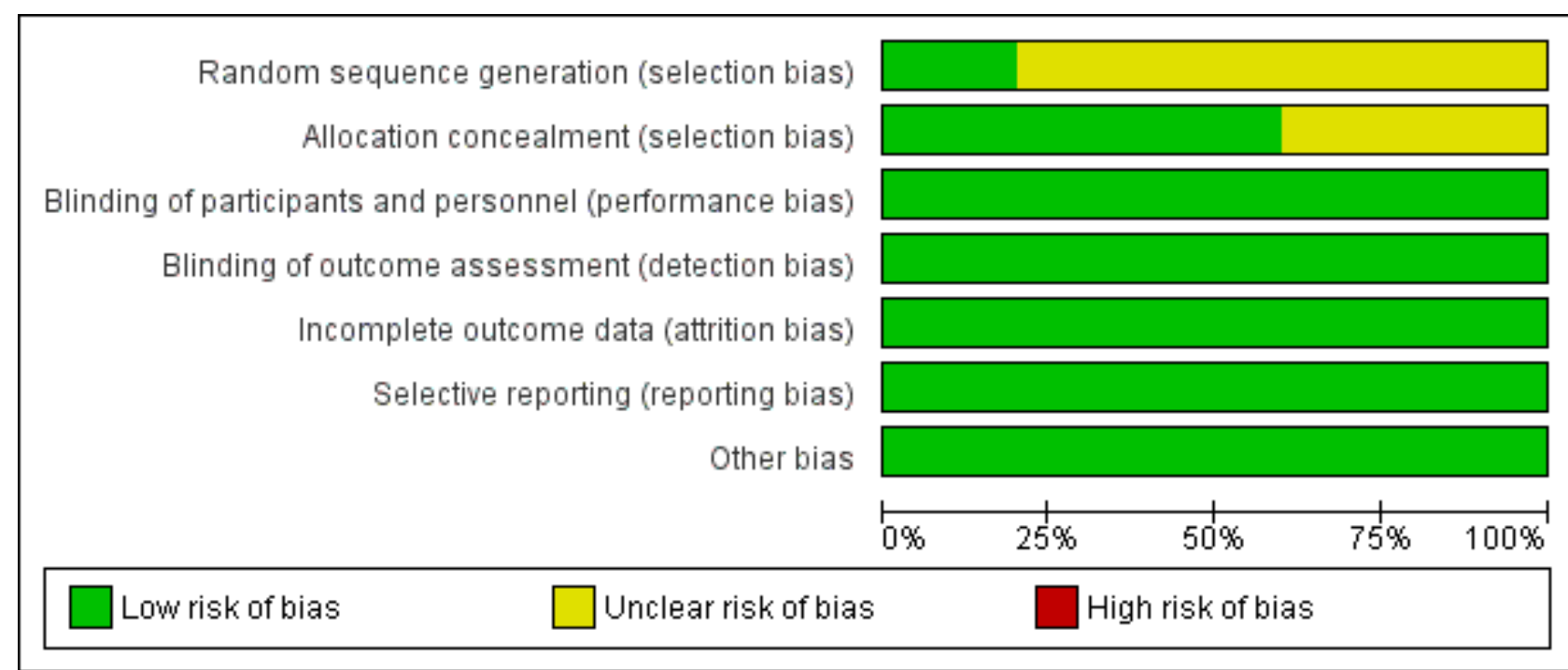


Figure 3. Risk of bias summary: review authors' judgements about each risk of bias item for each included study.

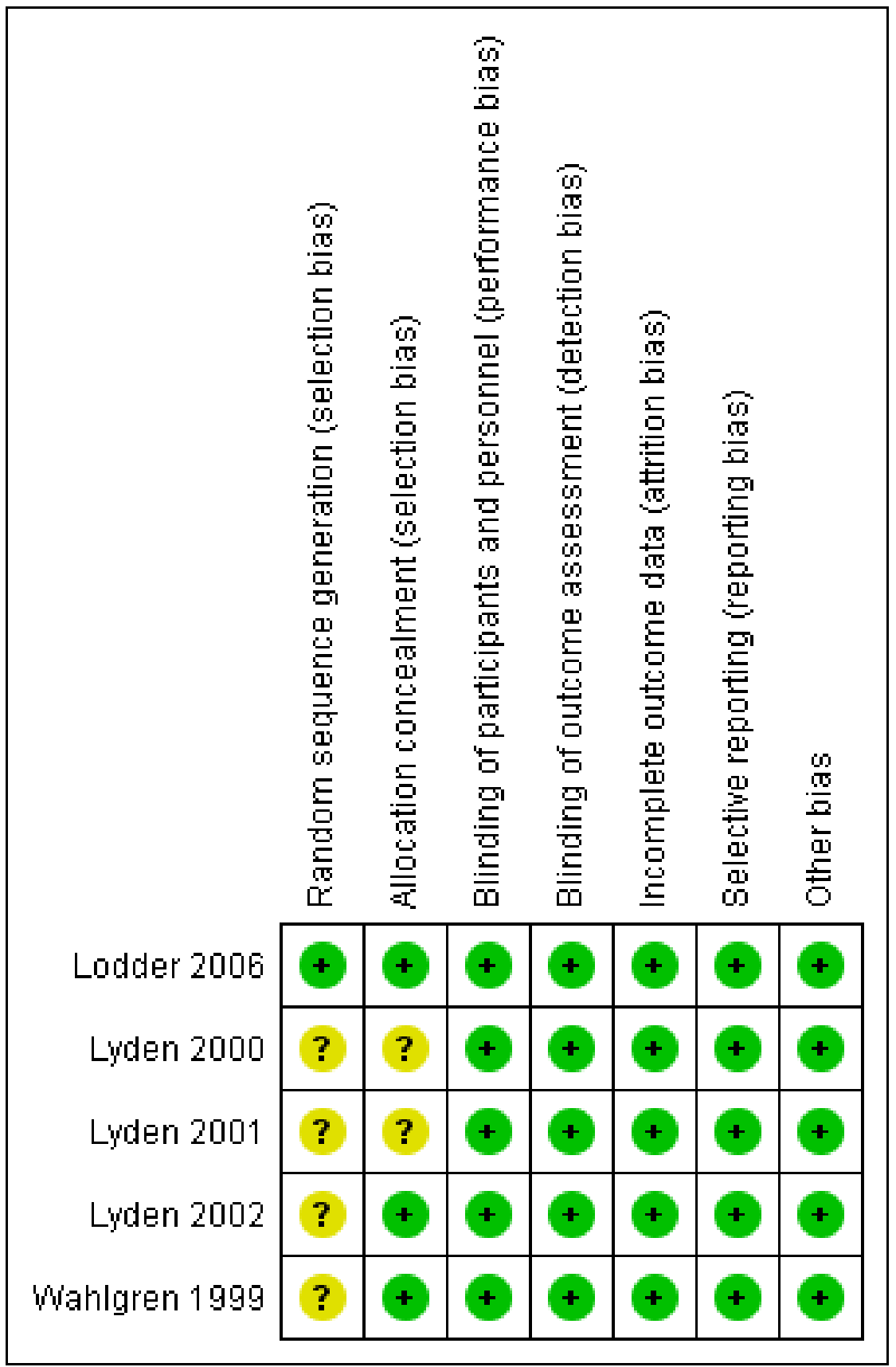

\section{Allocation}

All of the included trials stated that participants were randomized into intervention and placebo groups, but only one trial described the actual method of randomization and allocation concealment with low risk of bias (Lodder 2006). Therefore, we judged unclear risks of bias for the other four trials (Lyden 2000; Lyden 2001; Lyden 2002; Wahlgren 1999).

\section{Blinding}

All of the participants and investigators were blinded to the trial medication. We assessed blinding as low risk of bias.

\section{Incomplete outcome data}

All five studies reported the reason and number of participants who had discontinued treatment by the endpoint. Only one trial stated they had performed an intention-to-treat analysis (Lodder 2006). No more than $10 \%$ discontinued participants were found in any arm of each included trials. Therefore, we assessed this as low risk of bias.

\section{Selective reporting}

All of the pre-specified outcomes were reported. Therefore, we assessed this as low risk of bias. 


\section{Other potential sources of bias}

We did not find any potential publication bias. Insufficient numbers of trials were available for a funnel plot analysis.

\section{Effects of interventions}

See: Summary of findings for the main comparison Chlormethiazole compared with placebo for acute stroke; Summary of findings 2 Diazepam compared with placebo for acute stroke

\section{Primary outcome measures}

\section{Efficacy (death or dependency)}

Four trials with 2909 participants reported death and dependency at three months after chlormethiazole or placebo administration; $710 / 1457(49 \%)$ and $689 / 1452(47 \%)$ deaths or dependencies occurred in the chlormethiazole and placebo groups respectively (RR $1.03,95 \% \mathrm{Cl} 0.96$ to 1.11; moderate-quality evidence) (Lyden 2000; Lyden 2001; Lyden 2002; Wahlgren 1999). One trial, with 849 participants, comparing diazepam and placebo reported 206/428 $(48 \%)$ and $216 / 421(51 \%)$ deaths or dependencies in the diazepam and placebo groups respectively (RR $0.94,95 \% \mathrm{Cl} 0.82$ to 1.07 ; moderate-quality evidence) (Lodder 2006).

In total, 916/1885 (49\%) participants in the gamma aminobutyric acid (GABA) receptor agonists group and 905/1873 (48\%) participants in the placebo group had died or experienced dependency at three months (RR 1.01, 95\% Cl 0.95 to 1.08; Analysis 1.1).

\section{Safety (adverse events)}

All of the trials reported serious adverse events (SAEs). Four trials - Lyden 2000, Lyden 2001, Lyden 2002, and Wahlgren 1999 - compared chlormethiazole with placebo (moderate-quality evidence), and Lodder 2006 compared diazepam with placebo (moderate-quality evidence). We found no significant differences in either the number of participants with SAEs or the number of SAEs in all trials.

The more frequent adverse events in the chlormethiazole group, reported in two trials, were somnolence and rhinitis (Lyden 2002; Wahlgren 1999). In the chlormethiazole and placebo groups, $654 / 1266$ (52\%) participants and 142/1261 (11\%) participants respectively experienced somnolence (RR $4.56,95 \% \mathrm{Cl} 3.50$ to 5.95; Analysis 1.2) (moderate-quality evidence); while 165/1266 $(13 \%)$ participants and $32 / 1261(3 \%)$ participants respectively experienced rhinitis (RR 4.75, 95\% Cl 2.67 to 8.46; Analysis 1.3) (moderate-quality evidence). There was significant heterogeneity $\left(\mathrm{I}^{2}=62 \%\right.$ and $\mathrm{I}^{2}=53 \%$ respectively $)$ for these two outcomes; therefore, we used a random-effects model for the analyses.

\section{Secondary outcomes measures}

\section{Functional independence}

Functional independence, defined as a BI score higher than 60 or a mRS score less than 3, was measured in five trials (Analysis 1.4). Four trials compared chlormethiazole with placebo, with 747/1457 (51\%) participants and 763/1452 (53\%) participants respectively scoring more than 60 on the $\mathrm{BI}$ score (RR $0.98,95 \% \mathrm{Cl} 0.92$ to 1.05; moderate-quality evidence) (Lyden 2000; Lyden 2001; Lyden 2002; Wahlgren 1999). The Lodder 2006 trial of diazepam versus placebo reported that 222/428 (52\%) participants and 205/421 (49\%) participants respectively had a mRS score of less than three (RR 1.07, $95 \% \mathrm{Cl} 0.93$ to 1.22; moderate-quality evidence).

\section{Neurological function}

\section{National Institutes of Health Stroke Scale (NIHSS) score}

We had intended to calculate the mean change of NIHSS score; however, only two trials reported this and neither of them gave it as 'mean (SD)' (Lyden 2000; Lyden 2002). In Lyden 2000, the mean change in NIHSS score was -4.5 in the chlormethiazole group $(\mathrm{N}=$ $96)$ and -4.0 in the placebo group $(N=102 ; P=0.36)$. In Lyden 2002, the change in NIHSS score (median (quartiles)) was -5.5 ( -11 to 17$)$ in the chlormethiazole group ( $\mathrm{N}=586)$; and $-6.0(-10$ to 16$)$ in the placebo group ( $\mathrm{N}=583, \mathrm{P}=0.68)$ (moderate-quality evidence).

\section{Scandinavian Stroke Scale (SSS) score}

The results of the SSS score were given for three trials (Lyden 2000; Lyden 2002; Wahlgren 1999). In Wahlgren 1999, we found no significant difference between the placebo and chlormethiazole groups for the change in score in the 48-point Scandinavian Stroke Scale (SSS-48; P = 0.56) and the Scandinavian Stroke Scale motor power score (SSS-MP; P = 0.96). In Lyden 2000 and Lyden 2002, the change in score in the SSS was not significant in the two groups ( $P$ $=0.06$ and $\mathrm{P}=0.23$ respectively) (moderate-quality evidence).

\section{Subgroup analysis}

\section{Efficacy for acute ischemic stroke}

Three trials reported death and dependency at three months in the chlormethiazole and placebo groups in 652/1327 (49\%) and $628 / 1319$ (48\%) participants respectively (RR $1.04,95 \% \mathrm{Cl} 0.96$ to 1.12; Analysis 2.1) (Lyden 2001; Lyden 2002; Wahlgren 1999). The same three trials reported functional independence in 662/1327 (50\%) participants in the chlormethiazole group and 675/1319 (51\%) participants in the placebo group (RR $0.98,95 \% \mathrm{Cl} 0.91$ to 1.05). Lodder 2006 reported functional independence in 203/380 (53\%) participants in the diazepam group, and 178/368 (48\%) participants in the placebo group (RR $1.10,95 \% \mathrm{Cl} 0.96$ to 1.27 ; Analysis 2.2).

\section{Efficacy for acute hemorrhagic stroke}

Two trials reported death and dependency at three months in the chlormethiazole and placebo groups in 58/143 (41\%) and $61 / 149$ (41\%) participants respectively (RR $0.99,95 \% \mathrm{Cl} 0.75$ to 1.30; Analysis 3.1) (Lyden 2000; Wahlgren 1999). Functional independence was found in $85 / 143(59 \%)$ in the chlormethiazole group and $88 / 149(59 \%)$ in the placebo group (RR 1.00, 95\% Cl 0.83 to 1.21 ). In addition Lodder 2006, which tested diazepam versus placebo, found that $18 / 46(39 \%)$ and $24 / 49$ (49\%) participants respectively were functionally independent ( $\mathrm{RR} 0.80,95 \% \mathrm{Cl} 0.50$ to 1.27) (Analysis 3.2).

\section{Efficacy for total anterior circulation syndrome (TACS)}

For participants with a TACS, two trials measured functional independence at three months in the chlormethiazole and placebo groups (Lyden 2001; Wahlgren 1999). In total, 144/338 (43\%) participants and 94/297 (32\%) participants respectively were found to be functionally independent (RR $1.33,95 \% \mathrm{Cl} 1.08$ to 1.63 ; Analysis 4.1). 


\section{Efficacy for early-treated acute stroke}

We extracted data for early-treated acute stroke. Two trials reported functional independence at three months in participants treated within six hours of stroke onset, in 267/590 (45\%) participants in the chlormethiazole group and 282/592 (48\%) participants in the placebo group (RR 0.93, 95\% Cl 0.73 to 1.19) (Lyden 2002; Wahlgren 1999). Lodder 2006 defined early treatment as within three hours of onset and measured functional independence at three months in the diazepam and placebo groups: $37 / 70$ (53\%) participants and $27 / 62(44 \%)$ participants respectively were reported to be functionally independent (RR $1.21,95 \% \mathrm{Cl} 0.85$ to 1.74 ) (Analysis 5.1).

\section{Sensitivity analysis}

\section{Fixed-effect versus random-effects models}

We calculated the overall effects using a random-effects model, regardless of the level of heterogeneity. We also assessed the robustness of results in fixed-effect versus random-effects models. We found no changes in the results.

\section{Excluding studies with potential selection bias}

Only one trial clearly described random sequence generation and allocation concealment, and it was the only trial of diazepam for acute stroke (Lodder 2006); the other trials tested chlormethiazole. Thus, the data were inadequate to conduct a sensitivity analysis.

\section{DISCUSSION}

\section{Summary of main results}

We included five eligible trials with 3838 participants (3758 analyzed) in our review. The methodological quality of the included trials was generally good, with an unclear risk for selection bias only. There was no convincing evidence to support the use of gamma aminobutyric acid (GABA) receptor agonists (chlormethiazole or diazepam) for treating people with acute ischemic or hemorrhagic stroke.

Our primary outcomes were efficacy and safety. Four trials reported death and dependency at three months in the chlormethiazole versus placebo groups; we found no significant difference (RR 1.03, $95 \% \mathrm{Cl} 0.96$ to 1.11). One trial reported this outcome for diazepam versus placebo (RR $0.94,95 \% \mathrm{Cl} 0.82$ to 1.07 ).

The most frequent adverse events caused by chlormethiazole were somnolence (RR 4.56, 95\% $\mathrm{Cl} 3.50$ to 5.95) and rhinitis (RR 4.75, 95\% $\mathrm{Cl} 2.67$ to 8.46 ; two trials).

\section{Overall completeness and applicability of evidence}

None of the included studies demonstrated benefits from GABA receptor agonists (chlormethiazole or diazepam) for people with acute stroke when compared with placebo; that is, we found neither a decrease in death or dependency, nor an increase in functional independence. The subgroup analysis for those with total anterior circulation syndrome (TACS) illustrated a positive result, based on only two studies. Meanwhile, the subgroup analysis for acute hemorrhagic stroke did not find an increase in death or dependency, which meant that GABA receptor agonists did not appear to cause harm in hemorrhagic stroke when compared with placebo. Readers should note these conclusions need further confirmation by more RCTs with large samples. At present, no clear evidence supports the clinical administration of GABA receptor agonists in any type of acute stroke.

\section{Quality of the evidence}

This review provides moderate-quality evidence. The search methods were rigorous and well performed. The methodological quality of the included trials was generally good, with an unclear risk for selection bias only. We also specified the reasons for excluding trials. However, the conclusions from subgroup analyses should be interpreted with caution, due to the limitations of the available data.

\section{Potential biases in the review process}

Some data were not provided for subgroup analyses. For instance, the Wahlgren 1999 study included 1360 participants with acute stroke, $7 \%$ of whom (95 participants) had a hemorrhagic stroke. However they did not provide the independent data for ischemic stroke, and we used subtraction to calculate the ischemic stroke data for the outcomes. This may have led to potential bias.

\section{Agreements and disagreements with other studies or reviews}

We found only one review on this topic, which mainly focused on the pharmacokinetics of chlormethiazole in people with acute stroke (Zingmark 2003). Therefore it is not comparable, because of the different objectives and outcomes.

\section{AUTHORS' CONCLUSIONS}

\section{Implications for practice}

This review provides moderate-quality evidence that fails to support the use of gamma aminobutyric acid (GABA) receptor agonists (chlormethiazole or diazepam) for the treatment of people with acute ischemic or hemorrhagic stroke. Somnolence and rhinitis appear to be the most frequent adverse events related to chlormethiazole, and further investigations are required.

\section{Implications for research}

Well-designed, double-blind RCTs would be required to test the efficacy of chlormethiazole in a large group of people with TACS.

\section{ACKNOWLEDGEMENTS}

The authors acknowledge the help provided by the Cochrane Stroke Group. 
R E F E R E N C E S

\section{References to studies included in this review}

Lodder 2006 \{published data only\}

* Lodder J, van Raak L, Hilton A, Hardy E, Kessels A. Diazepam to improve acute stroke outcome: results of the early GABAergic activation study in stroke trial. A randomized doubleblind placebo controlled trial. Cerebrovascular Diseases (Basel, Switzerland) 2006;21(1-2):120-7.

Van Raak L, Hilton A, Kessels F, Lodder J. Implementing the EGASIS trial, an international multicenter acute intervention trial in stroke. Controlled Clinical Trials 2002;23(1):74-9.

Lyden 2000 \{published data only\}

Lyden PD, Shuaib A, Ng K, Atkinson R, Ashwood T, Nordlund A, et al. The Clomethiazole Acute Stroke Study in Hemorrhagic Stroke (CLASS-H): final results. Journal of Stroke and Cerebrovascular Diseases 2000;9(6):268-75.

Lyden 2001 \{published data only\}

Lyden P, Jacoby M, Schim J, Albers G, Mazzeo P, Ashwood T, et al. The clomethiazole acute stroke study in tissue-type plasminogen activator-treated stroke (CLASS-T). Neurology 2001;57(7):1199-205.

\section{Lyden 2002 \{published data only\}}

* Lyden P, Shuaib A, Levin K, Atkinson RP, Rajput A, Wechsler L, et al. Clomethiazole acute stroke study in ischemic stroke (CLASS-I): final results. Stroke 2002;33(1):122-8.

Millis SR, Straube D, Iramaneerat C, Smith EV Jr, Lyden P. Measurement properties of the National Institutes of Health Stroke Scale for people with right- and left-hemisphere lesions: further analysis of the clomethiazole for Acute Stroke StudyIschemic (CLASS-I) trial. Archives of Physical Medicine and Rehabilitation 2007;88(3):302-8.

\section{Wahlgren 1999 \{published data only\}}

Wahlgren NG, Bornhov S, Sharma A, Cederin B, Rosolacci T, Ashwood T, et al. The Clomethiazole Acute Stroke Study (CLASS): Efficacy results in 545 patients classified as Total Anterior Circulation Syndrome (TACS). Journal of Stroke and Cerebrovascular Diseases 1999;8(4):231-9.

Wahlgren NG, Diez-Tejador E, Teitelbaum J, Arboix A, Leys D, Ashwood T, et al. Results in 95 hemorrhagic stroke patients included in CLASS, a controlled trial of clomethiazole versus placebo in acute stroke patients. Stroke 2000;31(1):82-5.

Wahlgren NG, Matias Guiu J, Lainez JM, Veloso F, Ranasinha K, Grossman E, et al. The Clomethiazole Acute Stroke Study (CLASS): safety results in 1,356 patients with acute hemispheric stroke. Journal of Stroke and Cerebrovascular Diseases 2000;9(4):158-65.

* Wahlgren NG, Ranasinha KW, Rosolacci T, Franke CL, Van Erven PM, Ashwood T, et al. Clomethiazole acute stroke study (CLASS). Results of a randomized, controlled trial of clomethiazole versus placebo in 1360 acute stroke patients. Stroke 1999;30(1):21-8.

\section{References to studies excluded from this review}

Agarwal 2017 \{published data only\}

Agarwal S, Patel T, Shah N, Patel BM. Comparative study of therapeutic response to baclofen vs tolperisone in spasticity. Biomedicine \& Pharmacotherapy 2017;87:628-35.

\section{Chow 2017 \{published data only\}}

Chow JW, Yablon SA, Stokic DS. Intrathecal baclofen bolus reduces exaggerated extensor coactivation during pre-swing and early-swing of gait after acquired brain injury. Clinical Neurophysiology 2017;128(5):725-33.

Darmani 2016 \{published data only\}

Darmani G, Zipser CM, Böhmer GM, Deschet K, MüllerDahlhaus F, Belardinelli P, et al. Effects of the selective a5GABAAR antagonist S44819 on excitability in the human brain: a TMS-EMG and TMS-EEG phase I study. Journal of Neuroscience 2016;36(49):12312-20.

Lyden 1998 \{published data only\}

Lyden PD, Ashwood T, Claesson L, Odergren T, Friday GH, Martin-Munley S. The clomethiazole acute stroke study in ischemic, hemorrhagic, and t-PA treated stroke: design of a phase III trial in the United States and Canada. Journal of Stroke and Cerebrovascular Diseases 1998;7(6):435-41.

Nepveu 2017 \{published data only\}

Nepveu JF, Thiel A, Tang A, Fung J, Lundbye-Jensen J, Boyd LA, et al. A single bout of high-intensity interval training improves motor skill retention in individuals with stroke. Neurorehabilitation and Neural Repair 2017;31(8):726-35.

Zhang 2014 \{published data only\}

Zhang C, Zhang R, Zhang S, Xu M, Zhang S. Baclofen for stroke patients with persistent hiccups: a randomized, double-blind, placebo-controlled trial. Trials 2014;15:295.

\section{Additional references}

\section{AHA 2002}

American Heart Association. 2002 Heart and Stroke Facts Statistical Update. Dallas: American Heart Association, 2002.

\section{Alicke 1995}

Alicke B, Schwartz-Bloom RD. Rapid down-regulation of GABAA receptors in the gerbil hippocampus following transient cerebral ischemia. Journal of Neurochemistry 1995;65(6):2808-11.

\section{Bath 2001}

Bath PM, Iddenden R, Bath FJ, Orgogozo JM, Tirilazad International Steering Committee. Tirilazad for acute ischemic stroke. Cochrane Database of Systematic Reviews 2001, Issue 4. [DOI: 10.1002/14651858.CD002087] 


\section{Bath 2004}

Bath PMW, Bath-Hextall FJ. Pentoxifylline, propentofylline and pentifylline for acute ischemic stroke. Cochrane Database of Systematic Reviews 2004, Issue 3. [DOI: 10.1002/14651858.CD000162.pub2]

\section{Candelise 2001}

Candelise L, Ciccone A. Gangliosides for acute ischemic stroke. Cochrane Database of Systematic Reviews 2001, Issue 4. [DOI: 10.1002/14651858.CD000094]

\section{Chi 2011}

Chi OZ, Hunter C, Liu X, Chi Y, Weiss HR. Effects of GABA(A) receptor blockade on regional cerebral blood flow and bloodbrain barrier disruption in focal cerebral ischemia. Journal of Neurological Sciences 2011;301((1-2)):66-70.

\section{Cruz-Flores 2011}

Cruz-Flores S. Ischemic stroke in emergency medicine. emedicine.medscape.com/article/1916852-overview (accessed 9 June 2011)

\section{Egger 1997}

Egger M, Davey Smith G, Schneider M, Minder C. Bias in meta-analysis detected by a simple graphical test. BMJ 1997;315(7109):629-34.

\section{Gandolfo 2002}

Gandolfo C, Sandercock P, Conti M. Lubeluzole for acute ischemic stroke. Cochrane Database of Systematic Reviews 2002, Issue 1. [DOI: 10.1002/14651858.CD001924]

\section{Gasior 2004}

Gasior M, Witkin JM, Goldberg SR, Munzar P. Chlormethiazole potentiates the discriminative stimulus effects of methamphetamine in rats. European Journal of Pharmacology 2004;494(2-3):183-9.

\section{Hanna 1996}

Hanna JP, Frank JI, Furlan AJ, Sila SA, Secic S. Prediction of worsening consciousness from edema after hemispheric infarction. Journal of Stroke and Cerebrovascular Diseases 1996;6(1):25-9.

\section{Higgins 2011}

Cochrane Handbook for Systematic Reviews of Interventions Version 5.1.0 (updated March 2011). The Cochrane Collaboration, 2011. Available from handbook.cochrane.org.

\section{Horn 2000}

Horn J, Limburg M. Calcium antagonists for acute ischemic stroke. Cochrane Database of Systematic Reviews 2000, Issue 1. [DOI: 10.1002/14651858.CD001928]

\section{Klassman 2011}

Klassman L. Therapeutic hypothermia in acute stroke. Journal of Neuroscience Nursing 2011;43(2):94-103.

\section{Marshall 2003}

Marshall JW, Green AR, Ridley RM. Comparison of the neuroprotective effect of clomethiazole, AR-R15896AR and
NXY-059 in a primate model of stroke using histological and behavioural measures. Brain Research 2003;972(1-2):119-26.

\section{Muir 2003}

Muir KW, Lees KR. Excitatory amino acid antagonists for acute stroke. Cochrane Database of Systematic Reviews 2003, Issue 3. [DOI: 10.1002/14651858.CD001244]

\section{Nelson 2000}

Nelson RM, Green AR, Lambert DG, Hainsworth AH. On the regulation of ischemia-induced glutamate efflux from rat cortex by GABA: in vitro studies with GABA, clomethiazole and pentobarbitone. British Journal of Pharmacology 2000;130(5):1124-30.

\section{Review Manager 2014 [Computer program]}

Nordic Cochrane Centre, The Cochrane Collaboration. Review Manager 5 (RevMan 5). Version 5.3. Copenhagen: Nordic Cochrane Centre, The Cochrane Collaboration, 2014.

\section{Saka 2009}

Saka O, McGuire A, Wolfe C. Cost of stroke in the United Kingdom. Age and Ageing 2009;38(1):27-32.

\section{Simon 2009}

Simon RP, Greenberg DA, Aminoff MJ. Stroke. Clinical Neurology. 7th Edition. New York: McGraw-Hill, 2009:292-327.

\section{Sulter 1999}

Sulter G, Steen C, De Keyser J. Use of the Barthel index and modified Rankin scale in acute stroke trials. Stroke 1999;30(8):1538-41.

\section{Sydserff 2002}

Sydserff SG, Borelli AR, Green AR, Cross AJ. Effect of NXY-059 on infarct volume after transient or permanent middle cerebral artery occlusion in the rat: studies on dose, plasma concentration and therapeutic time window. British Journal of Pharmacology 2002;135(1):103-12.

\section{Tuttolomondo 2009}

Tuttolomondo A, Di Sciacca R, Di Raimondo D, Arnao V, Renda C, Pinto A, et al. Neuron protection as a therapeutic target in acute ischemic stroke. Current Topics in Medicinal Chemistry 2009;9(14):1317-34.

\section{Vaishnav 2002}

Vaishnav A, Lutsep HL. GABA agonist: clomethiazole. Current Medical Research and Opinion 2002;18(Suppl 2):S5-8.

\section{Visser 2005}

Visser SA, Pozarek S, Martinsson S, Forsberg T, Ross SB, Gabrielsson J. Rapid and long-lasting tolerance to clomethiazole-induced hypothermia in the rat. European Journal of Pharmacology 2005;512(2-3):139-51.

\section{Warlow 2001}

Warlow CP, Dennis MS, van Gijn J, Hankey GJ, Sandercock PAG, Bamford JM, et al. What caused this transient or persistent ischemic event?. Stroke: A Practical Guide to Management. 2nd Edition. Oxford: Wiley-Blackwell, 2001. 


\section{WHO 2011}

World Health Organization. The atlas of heart disease and stroke. who.int/cardiovascular_diseases/resources/atlas/en (accessed 9 June 2011).

\section{Wilby 2004}

Wilby MJ, Hutchinson PJ. The pharmacology of chlormethiazole: a potential neuroprotective agent?. CNS Drug Reviews 2004;10(4):281-94.

\section{Zingmark 2003}

Zingmark PH, Ekblom M, Odergren T, Ashwood T, Lyden P, Karlsson MO, et al. Population pharmacokinetics of clomethiazole and its effect on the natural course of sedation in acute stroke patients. British Journal of Clinical Pharmacology 2003;56(2):173-83.

\section{Zubcevic 2010}

Zubcevic J, Potts JT. Role of GABAergic neurons in the nucleus tractus solitarii in modulation of cardiovascular activity. Experimental Physiology 2010;95(9):909-18.

\section{CHARACTERISTICS OF STUDIES}

\section{Characteristics of included studies [ordered by study ID]}

\section{References to other published versions of this review}

\section{Liu 2013}

Liu J, Wang LN. Gamma aminobutyric acid (GABA) receptor agonists for acute stroke. Cochrane Database of Systematic Reviews 2013, Issue 2. [DOI: 10.1002/14651858.CD009622.pub2]

\section{Liu 2014}

Liu J, Wang LN. Gamma aminobutyric acid (GABA) receptor agonists for acute stroke. Cochrane Database of Systematic Reviews 2014, Issue 8. [DOI: 10.1002/14651858.CD009622.pub3]

\section{Liu 2016}

Liu J, Wang LN. Gamma aminobutyric acid (GABA) receptor agonists for acute stroke. Cochrane Database of Systematic Reviews 2016, Issue 10. [DOI: 10.1002/14651858.CD009622.pub4]

* Indicates the major publication for the study

Lodder 2006

Methods A multicenter, randomized, stratified, double-blind, placebo-controlled clinical trial to examine the efficacy and safety of diazepam in acute stroke

Participants Adult males and females were included within 12 hours after stroke onset

CT or MRI within 7 days was mandatory

People with a clear indication for, or contraindication to, benzodiazepines (at the discretion of the attending physician) were excluded, as were people with unresponsive coma

879 eligible people from 35 hospitals in 5 European countries were randomized into the trial

Interventions Diazepam $10 \mathrm{mg}$ or placebo by rectiole, as soon as possible, followed by $10 \mathrm{mg}$ tablets twice daily for 3
days versus placebo

Outcomes Independence $(\mathrm{mRS}<3)$; complete recovery $(\mathrm{BI} \geqq 95$ or $\mathrm{mRS} \leqq 1)$; adverse events; mortality

Notes Follow-up: 3 months

\section{Risk of bias}

\begin{tabular}{lll}
\hline Bias & Authors' judgement & Support for judgement \\
\hline $\begin{array}{l}\text { Random sequence genera- } \\
\text { tion (selection bias) }\end{array}$ & Low risk & $\begin{array}{l}\text { Participants were randomized using a computer-generated random listing of } \\
\text { the } 2 \text { treatment assignments, blocked in groups of } 4 \text { and stratified for center }\end{array}$ \\
\hline $\begin{array}{l}\text { Allocation concealment } \\
\text { (selection bias) }\end{array}$ & Low risk & $\begin{array}{l}\text { Trial medication was packed and labeled by the hospital's pharmacist accord- } \\
\text { ing to a medication code schedule generated before the trial, and sent to the } \\
\text { participating centers in boxes of } 20 \text { treatment packs }\end{array}$ \\
\hline $\begin{array}{l}\text { Blinding of participants } \\
\text { and personnel (perfor- } \\
\text { mance bias) }\end{array}$ & Low risk & All the participants were blinded to trial medication \\
\hline
\end{tabular}


Lodder 2006 (Continued)

All outcomes

\begin{tabular}{|c|c|c|}
\hline $\begin{array}{l}\text { Blinding of outcome as- } \\
\text { sessment (detection bias) } \\
\text { All outcomes }\end{array}$ & Low risk & $\begin{array}{l}\text { All the investigators, treating physicians and nurses were blinded to trial med- } \\
\text { ication }\end{array}$ \\
\hline $\begin{array}{l}\text { Incomplete outcome data } \\
\text { (attrition bias) } \\
\text { All outcomes }\end{array}$ & Low risk & $\begin{array}{l}31 \text { participants }(3.5 \%) \text { discontinued the study after randomization, with explic- } \\
\text { it reasons }\end{array}$ \\
\hline $\begin{array}{l}\text { Selective reporting (re- } \\
\text { porting bias) }\end{array}$ & Low risk & All pre-specified outcomes were reported \\
\hline Other bias & Low risk & All efficacy and safety outcomes were analyzed by intention-to-treat \\
\hline
\end{tabular}

Lyden 2000

$\begin{array}{ll}\text { Methods } & \begin{array}{l}\text { The safety of chlormethiazole versus placebo in hemorrhagic stroke patients was evaluated in a ran- } \\ \text { domized, double-blind trial }\end{array}\end{array}$

Participants

Conscious participants aged 18 to 90 years were included within 12 hours after stroke onset

201 eligible participants were recruited and randomized into the trial

\begin{tabular}{ll}
\hline Interventions & Chlormethiazole $(68 \mathrm{mg} / \mathrm{kg})$ or placebo was given as an intravenous infusion over a 24-hour period \\
\hline Outcomes & Adverse events; mortality; independence $(\mathrm{BI} \geqq 60$ or mRS $<3)$; NIHSS; SSS-48 \\
\hline Notes & Follow-up: 3 months \\
\hline
\end{tabular}

\section{Risk of bias}

\begin{tabular}{|c|c|c|}
\hline Bias & Authors' judgement & Support for judgement \\
\hline $\begin{array}{l}\text { Random sequence genera- } \\
\text { tion (selection bias) }\end{array}$ & Unclear risk & The method of random sequence generation was not described \\
\hline $\begin{array}{l}\text { Allocation concealment } \\
\text { (selection bias) }\end{array}$ & Unclear risk & The allocation concealment was not reported \\
\hline $\begin{array}{l}\text { Blinding of participants } \\
\text { and personnel (perfor- } \\
\text { mance bias) } \\
\text { All outcomes }\end{array}$ & Low risk & $\begin{array}{l}\text { Chlormethiazole and placebo were supplied in identical bottles to keep the } \\
\text { treatment assignment blinded }\end{array}$ \\
\hline $\begin{array}{l}\text { Blinding of outcome as- } \\
\text { sessment (detection bias) } \\
\text { All outcomes }\end{array}$ & Low risk & $\begin{array}{l}\text { All the measurements were made by an assessor who was not involved during } \\
\text { the administration of the study drug, to maintain blinding of treatment assign- } \\
\text { ment }\end{array}$ \\
\hline $\begin{array}{l}\text { Incomplete outcome data } \\
\text { (attrition bias) } \\
\text { All outcomes }\end{array}$ & Low risk & $\begin{array}{l}\text { The study drug was not administered to } 1 \text { participant in the chlormethiazole } \\
\text { group and to } 2 \text { participants in the placebo group. Therefore, } 3 / 201 \text { (1\%) partic- } \\
\text { ipants were not included in the analysis of safety or efficacy }\end{array}$ \\
\hline $\begin{array}{l}\text { Selective reporting (re- } \\
\text { porting bias) }\end{array}$ & Low risk & All pre-specified outcomes were reported \\
\hline
\end{tabular}


Lyden 2000 (Continued)
Other bias
Low risk
No other bias was found

Lyden 2001

Methods A randomized, double-blind, multicenter, placebo-controlled study to explore the safety of t-PA combined with chlormethiazole

\begin{tabular}{ll}
\hline Participants & $\begin{array}{l}\text { There were } 101 \text { participants randomized to the chlormethiazole group and } 99 \text { to the placebo group by } \\
76 \text { of the } 142 \text { hospitals involved in the study }\end{array}$ \\
\hline Interventions & $\begin{array}{l}\text { All participants received } 0.9 \mathrm{mg} / \mathrm{kg} \mathrm{t}-\mathrm{PA}, \text { beginning within } 3 \text { hours of stroke onset and then either } 68 \\
\mathrm{mg} / \mathrm{kg} \text { chlormethiazole }(\mathrm{N}=97) \text { iv over } 24 \text { hours or placebo }(\mathrm{N}=93) \text { beginning within } 12 \text { hours of stroke } \\
\text { onset }\end{array}$
\end{tabular}

Outcomes $\quad$ Adverse events; mortality; independence $(\mathrm{BI} \geqq 60)$

Notes Follow-up: 3 months

\section{Risk of bias}

\begin{tabular}{|c|c|c|}
\hline Bias & Authors' judgement & Support for judgement \\
\hline $\begin{array}{l}\text { Random sequence genera- } \\
\text { tion (selection bias) }\end{array}$ & Unclear risk & $\begin{array}{l}\text { The stratified randomization was implemented but the method of random se- } \\
\text { quence generation was not described }\end{array}$ \\
\hline $\begin{array}{l}\text { Allocation concealment } \\
\text { (selection bias) }\end{array}$ & Unclear risk & The allocation concealment was not reported \\
\hline $\begin{array}{l}\text { Blinding of participants } \\
\text { and personnel (perfor- } \\
\text { mance bias) } \\
\text { All outcomes }\end{array}$ & Low risk & $\begin{array}{l}\text { Chlormethiazole and placebo were supplied in identical bottles to keep the } \\
\text { treatment assignment blinded }\end{array}$ \\
\hline $\begin{array}{l}\text { Blinding of outcome as- } \\
\text { sessment (detection bias) } \\
\text { All outcomes }\end{array}$ & Low risk & $\begin{array}{l}\text { All the measurements were made by an assessor who was not involved during } \\
\text { the administration of the study drug, to maintain blinding of treatment assign- } \\
\text { ment }\end{array}$ \\
\hline $\begin{array}{l}\text { Incomplete outcome data } \\
\text { (attrition bias) } \\
\text { All outcomes }\end{array}$ & Low risk & $\begin{array}{l}\text { After randomization, } 10 / 200(5 \%) \text { participants ( } 4 \text { in the chlormethiazole group } \\
\text { and } 6 \text { in the placebo group) did not receive the study drug and thus were not } \\
\text { included in the safety analysis. All } 10 \text { participants showed signs of clinical de- } \\
\text { terioration after randomization before the study drug could be initiated }\end{array}$ \\
\hline $\begin{array}{l}\text { Selective reporting (re- } \\
\text { porting bias) }\end{array}$ & Low risk & All pre-specified outcomes were reported \\
\hline Other bias & Low risk & No other bias was found \\
\hline
\end{tabular}

Lyden 2002

$\begin{array}{ll}\text { Methods } & \begin{array}{l}\text { A randomized, double-blind, multinational, placebo-controlled investigation of the efficacy and safety } \\ \text { of chlormethiazole for acute ischemic stroke }\end{array}\end{array}$
of chlormethiazole for acute ischemic stroke

Participants Conscious participants aged 18 to 90 years were included within 12 hours after stroke onset. 
Lyden 2002 (Continued)

NIHSS score $\geqq 3$.

1198 eligible participants were recruited from 139 US and 14 Canadian centers and randomized into the trial

\begin{tabular}{ll}
\hline Interventions & Chlormethiazole $(68 \mathrm{mg} / \mathrm{kg})$ or placebo was given as an intravenous infusion over a 24-hour period \\
\hline Outcomes & Independence $(\mathrm{BI} \geqq 60$ or mRS < 3); NIHSS; SSS-48; adverse events; mortality \\
\hline Notes & Follow-up: 3 months
\end{tabular}

\section{Risk of bias}

\begin{tabular}{|c|c|c|}
\hline Bias & Authors' judgement & Support for judgement \\
\hline $\begin{array}{l}\text { Random sequence genera- } \\
\text { tion (selection bias) }\end{array}$ & Unclear risk & The method of random sequence generation was not described \\
\hline $\begin{array}{l}\text { Allocation concealment } \\
\text { (selection bias) }\end{array}$ & Low risk & $\begin{array}{l}\text { The allocation was conducted by a central randomization scheme via tele- } \\
\text { phone }\end{array}$ \\
\hline $\begin{array}{l}\text { Blinding of participants } \\
\text { and personnel (perfor- } \\
\text { mance bias) } \\
\text { All outcomes }\end{array}$ & Low risk & $\begin{array}{l}\text { Chlormethiazole and placebo were supplied in identical bottles to keep the } \\
\text { treatment assignment blinded }\end{array}$ \\
\hline $\begin{array}{l}\text { Blinding of outcome as- } \\
\text { sessment (detection bias) } \\
\text { All outcomes }\end{array}$ & Low risk & $\begin{array}{l}\text { All the measurements were made by an assessor who was not involved during } \\
\text { the administration of the study drug, to maintain blinding of treatment assign- } \\
\text { ment }\end{array}$ \\
\hline $\begin{array}{l}\text { Incomplete outcome data } \\
\text { (attrition bias) } \\
\text { All outcomes }\end{array}$ & Low risk & $\begin{array}{l}\text { Data from } 29 / 1198(2 \%) \text { participants were not available for the efficacy analy- } \\
\text { sis. Treatment was never started in } 27 \text { participants: } 12 \text { in the chlormethiazole } \\
\text { group and } 15 \text { in the placebo group. In addition, } 2 \text { participants ( } 1 \text { per group) } \\
\text { provided no efficacy data but were included in the safety analysis }\end{array}$ \\
\hline $\begin{array}{l}\text { Selective reporting (re- } \\
\text { porting bias) }\end{array}$ & Low risk & All pre-specified outcomes were reported \\
\hline Other bias & Low risk & No other bias was found \\
\hline
\end{tabular}

\section{Wahlgren 1999}

Methods Randomized, double-blind, multicenter, placebo-controlled study to test the efficacy and safety of the
neuroprotective drug chlormethiazole for acute stroke

Participants
The symptoms should have lasted more than 1 hour and less than 12 hours.
SSS-48 of $\leqq 40$, with a sum of scores on arm, hand and leg motor items of $\leqq 14$.
1360 eligible participants from 85 clinical centers in 7 European countries and Canada were random-
ized; 546 participants had TACS and 95 participants had hemorrhagic stroke

\begin{tabular}{ll}
\hline Interventions & Chlormethiazole $(75 \mathrm{mg} / \mathrm{kg})$ or placebo were given as an intravenous infusion over a 24-hour period \\
\hline Outcomes & Independence $(\mathrm{BI} \geqq 60)$; SSS-48; SSS-MP; adverse events; mortality
\end{tabular}


Wahlgren 1999 (Continued)
Notes
Follow-up: 3 months

\section{Risk of bias}

\begin{tabular}{|c|c|c|}
\hline Bias & Authors' judgement & Support for judgement \\
\hline $\begin{array}{l}\text { Random sequence genera- } \\
\text { tion (selection bias) }\end{array}$ & Unclear risk & $\begin{array}{l}\text { Randomization was stratified by center, but the method of random sequence } \\
\text { generation was not described }\end{array}$ \\
\hline $\begin{array}{l}\text { Allocation concealment } \\
\text { (selection bias) }\end{array}$ & Low risk & All validations were made with the treatment allocation blinded \\
\hline $\begin{array}{l}\text { Blinding of participants } \\
\text { and personnel (perfor- } \\
\text { mance bias) } \\
\text { All outcomes }\end{array}$ & Low risk & $\begin{array}{l}\text { Only the independent data monitoring committee had access to unblinded da- } \\
\text { ta during the course of the study }\end{array}$ \\
\hline $\begin{array}{l}\text { Blinding of outcome as- } \\
\text { sessment (detection bias) } \\
\text { All outcomes }\end{array}$ & Low risk & $\begin{array}{l}\text { Only the independent data monitoring committee had access to unblinded da- } \\
\text { ta during the course of the study }\end{array}$ \\
\hline $\begin{array}{l}\text { Incomplete outcome data } \\
\text { (attrition bias) } \\
\text { All outcomes }\end{array}$ & Low risk & $\begin{array}{l}16 / 1360(1 \%) \text { randomized participants did not complete the study. } \\
4 \text { participants did not receive treatment ( } 1 \text { randomized to chlormethiazole, } 3 \\
\text { to placebo). } \\
4 / 1360(0.3 \%) \text { randomized participants were not available for the safety analy- } \\
\text { sis. } \\
\text { In subgroup analyses, data from } 1 / 95(1 \%) \text { randomized hemorrhagic stroke } \\
\text { participants and } 6 / 546(1 \%) \text { randomized TACS participants were not available } \\
\text { for analysis }\end{array}$ \\
\hline $\begin{array}{l}\text { Selective reporting (re- } \\
\text { porting bias) }\end{array}$ & Low risk & All pre-specified outcomes were reported \\
\hline Other bias & Low risk & No other bias was found \\
\hline
\end{tabular}

BI: Barthel Index score

$\mathrm{CT}$ : computerized tomography

iv: intravenous

MRI: magnetic resonance imaging

mRS: modified Rankin Scale

NIHSS: National Institutes of Health Stroke Scale

SSS-48: 48-point Scandinavian Stroke Scale

SSS-MP: Scandinavian Stroke Scale motor power score

t-PA: tissue-type plasminogen activator

TACS: total anterior circulation syndrome

Characteristics of excluded studies [ordered by study ID]

\begin{tabular}{ll}
\hline Study & Reason for exclusion \\
\hline Agarwal 2017 & The participants were not eligible \\
\hline Chow 2017 & The participants were not eligible \\
\hline
\end{tabular}




\begin{tabular}{ll}
\hline Study & Reason for exclusion \\
\hline Darmani 2016 & The participants were not eligible \\
\hline Lyden 1998 & Neurological outcome of patients was not addressed \\
\hline Nepveu 2017 & The participants were not eligible \\
\hline Zhang 2014 & The participants were not eligible \\
\hline
\end{tabular}

$\mathrm{RCT}$ : randomized controlled trial

\section{DATA AND ANALYSES}

\section{Comparison 1. Efficacy and safety for acute stroke}

\begin{tabular}{|c|c|c|c|c|}
\hline Outcome or subgroup title & No. of studies & $\begin{array}{l}\text { No. of partici- } \\
\text { pants }\end{array}$ & Statistical method & Effect size \\
\hline 1 Death or dependency & 5 & 3758 & Risk Ratio (M-H, Random, 95\% Cl) & $1.01[0.95,1.08]$ \\
\hline $\begin{array}{l}1.1 \text { Chlormethiazole versus } \\
\text { placebo }\end{array}$ & 4 & 2909 & Risk Ratio (M-H, Random, 95\% Cl) & $1.03[0.96,1.11]$ \\
\hline 1.2 Diazepam versus placebo & 1 & 849 & Risk Ratio (M-H, Random, 95\% Cl) & $0.94[0.82,1.07]$ \\
\hline 2 Somnolence & 2 & 2527 & Risk Ratio (M-H, Random, 95\% Cl) & $4.56[3.50,5.95]$ \\
\hline $\begin{array}{l}2.1 \text { Chlormethiazole versus } \\
\text { placebo }\end{array}$ & 2 & 2527 & Risk Ratio (M-H, Random, 95\% Cl) & $4.56[3.50,5.95]$ \\
\hline 3 Rhinitis & 2 & 2527 & Risk Ratio (M-H, Random, 95\% Cl) & $4.75[2.67,8.46]$ \\
\hline $\begin{array}{l}3.1 \text { Chlormethiazole versus } \\
\text { placebo }\end{array}$ & 2 & 2527 & Risk Ratio (M-H, Random, 95\% Cl) & $4.75[2.67,8.46]$ \\
\hline 4 Functional independence & 5 & 3758 & Risk Ratio (M-H, Random, 95\% Cl) & $1.00[0.94,1.06]$ \\
\hline $\begin{array}{l}4.1 \text { Chlormethiazole versus } \\
\text { placebo }\end{array}$ & 4 & 2909 & Risk Ratio (M-H, Random, 95\% Cl) & $0.98[0.92,1.05]$ \\
\hline 4.2 Diazepam versus placebo & 1 & 849 & Risk Ratio (M-H, Random, 95\% Cl) & $1.07[0.93,1.22]$ \\
\hline
\end{tabular}

Analysis 1.1. Comparison 1 Efficacy and safety for acute stroke, Outcome 1 Death or dependency.

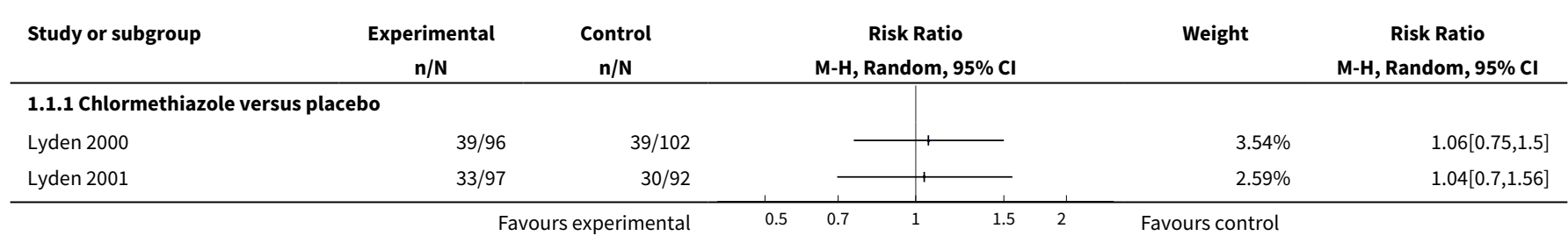




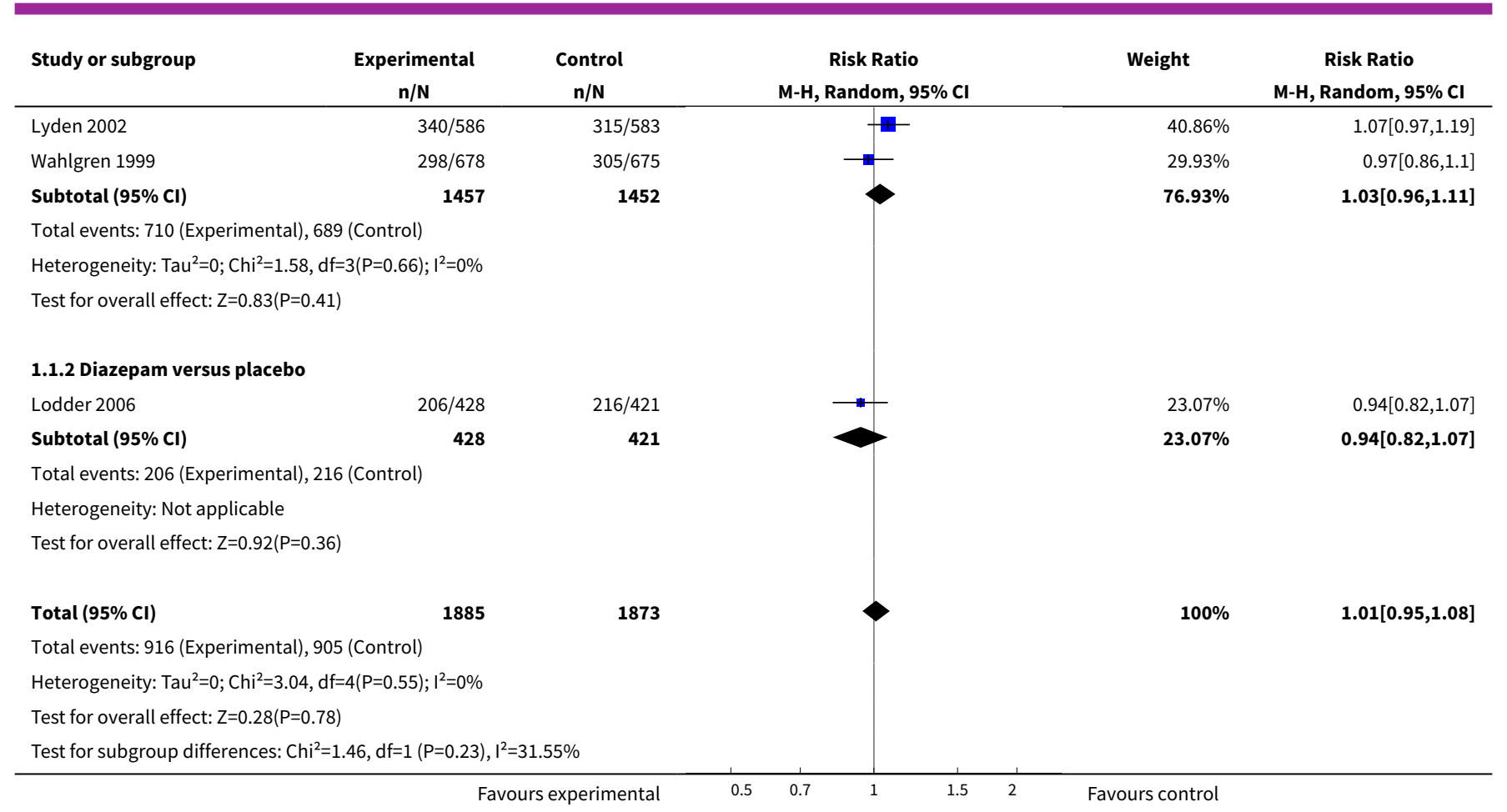

Analysis 1.2. Comparison 1 Efficacy and safety for acute stroke, Outcome 2 Somnolence.

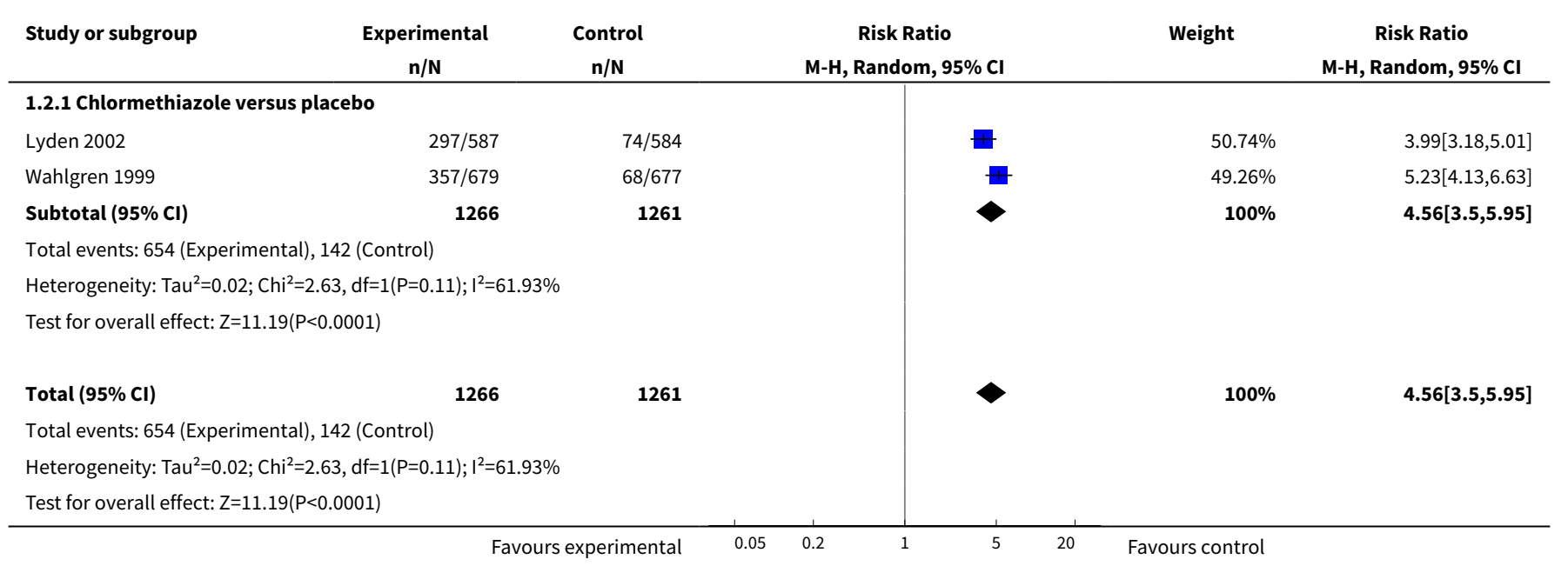

Analysis 1.3. Comparison 1 Efficacy and safety for acute stroke, Outcome 3 Rhinitis.

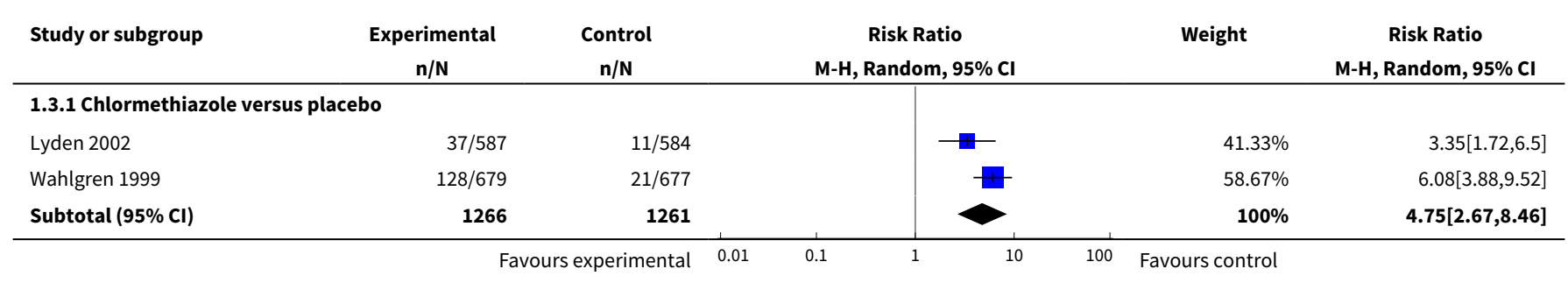




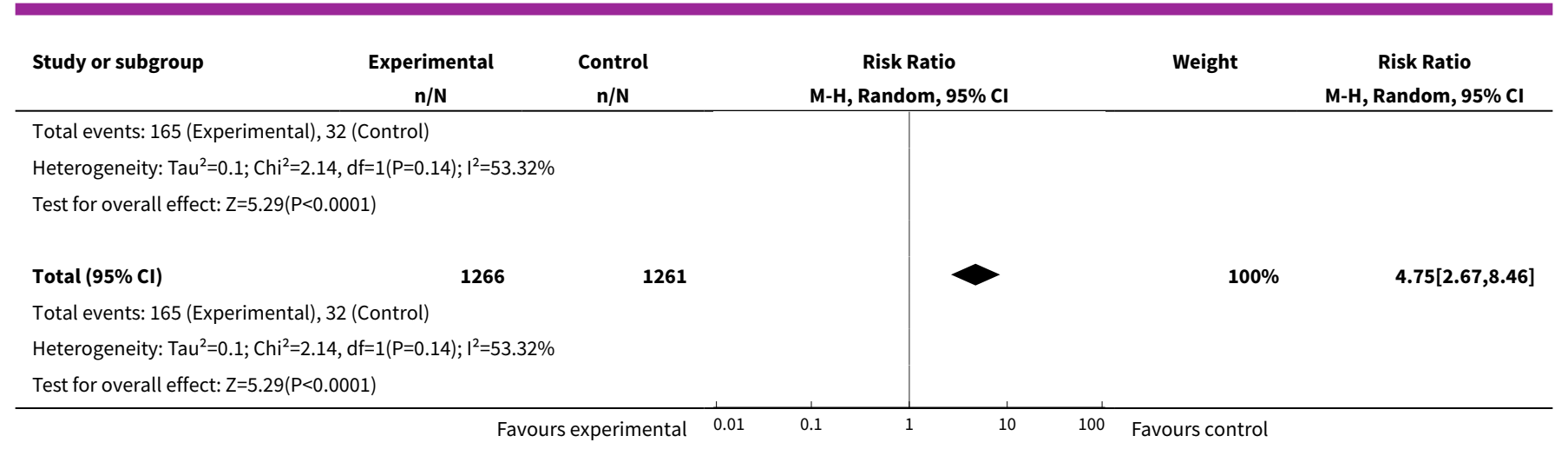

\section{Analysis 1.4. Comparison 1 Efficacy and safety for acute stroke, Outcome 4 Functional independence.}

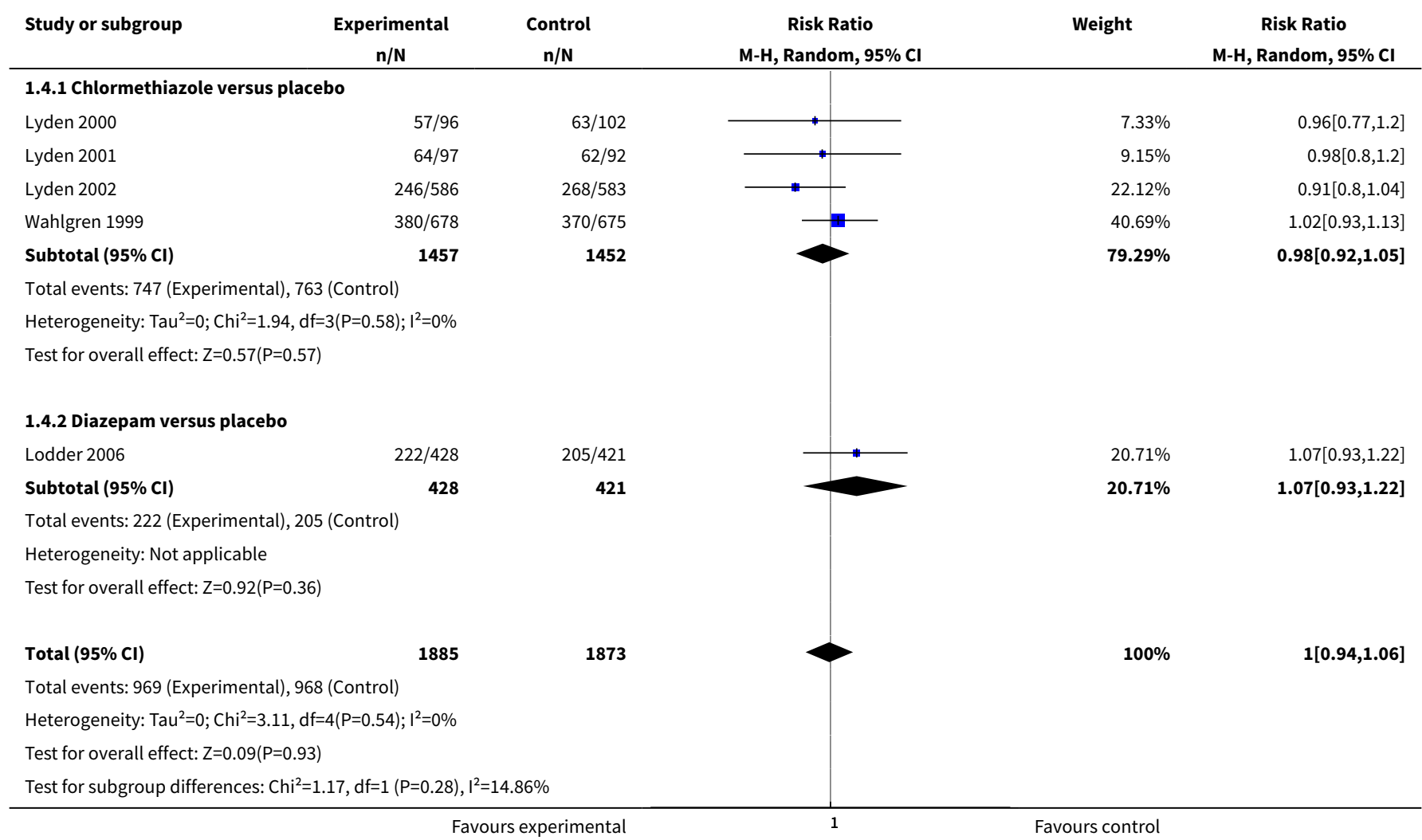

\section{Comparison 2. Efficacy for acute ischemic stroke}

\begin{tabular}{lllll}
\hline Outcome or subgroup title & No. of studies & $\begin{array}{l}\text { No. of partici- } \\
\text { pants }\end{array}$ & Statistical method & Effect size \\
\hline 1 Death or dependency & 3 & 2646 & Risk Ratio (M-H, Random, 95\% Cl) & $1.04[0.96,1.12]$ \\
\hline $\begin{array}{l}1.1 \text { Chlormethiazole versus } \\
\text { placebo }\end{array}$ & 3 & 2646 & Risk Ratio (M-H, Random, 95\% Cl) & $1.04[0.96,1.12]$ \\
\hline
\end{tabular}




\begin{tabular}{lllll}
\hline Outcome or subgroup title & No. of studies & $\begin{array}{l}\text { No. of partici- } \\
\text { pants }\end{array}$ & Statistical method & Effect size \\
\hline 2 Functional independence & 4 & 3394 & Risk Ratio (M-H, Random, 95\% Cl) & $1.00[0.93,1.08]$ \\
\hline $\begin{array}{l}2.1 \text { Chlormethiazole versus } \\
\text { placebo }\end{array}$ & 3 & 2646 & Risk Ratio (M-H, Random, 95\% Cl) & $0.98[0.91,1.05]$ \\
\hline \begin{tabular}{l}
2.2 Diazepam versus placebo \\
\hline
\end{tabular} & 1 & 748 & Risk Ratio (M-H, Random, 95\% Cl) & $1.10[0.96,1.27]$ \\
\hline
\end{tabular}

Analysis 2.1. Comparison 2 Efficacy for acute ischemic stroke, Outcome 1 Death or dependency.

\begin{tabular}{|c|c|c|c|c|c|}
\hline Study or subgroup & $\begin{array}{c}\text { Experimental } \\
n / N\end{array}$ & $\begin{array}{c}\text { Control } \\
n / N\end{array}$ & $\begin{array}{c}\text { Risk Ratio } \\
\text { M-H, Random, } 95 \% \mathrm{Cl}\end{array}$ & Weight & $\begin{array}{c}\text { Risk Ratio } \\
\text { M-H, Random, 95\% Cl }\end{array}$ \\
\hline \multicolumn{6}{|c|}{ 2.1.1 Chlormethiazole versus placebo } \\
\hline Lyden 2001 & $33 / 97$ & $30 / 92$ & & $3.69 \%$ & $1.04[0.7,1.56]$ \\
\hline Lyden 2002 & $340 / 599$ & $315 / 599$ & & $56.49 \%$ & $1.08[0.97,1.2]$ \\
\hline Wahlgren 1999 & $279 / 631$ & $283 / 628$ & & $39.81 \%$ & $0.98[0.87,1.11]$ \\
\hline Subtotal $(95 \% \mathrm{Cl})$ & 1327 & 1319 & & $100 \%$ & $1.04[0.96,1.12]$ \\
\hline \multicolumn{6}{|c|}{ Heterogeneity: $\mathrm{Tau}^{2}=0 ; \mathrm{Chi}^{2}=1.37, \mathrm{df}=2(\mathrm{P}=0.5) ; \mathrm{I}^{2}=0 \%$} \\
\hline \multicolumn{6}{|c|}{ Test for overall effect: $Z=0.94(P=0.35)$} \\
\hline Total $(95 \% \mathrm{Cl})$ & 1327 & 1319 & & $100 \%$ & $1.04[0.96,1.12]$ \\
\hline \multicolumn{6}{|c|}{ Total events: 652 (Experimental), 628 (Control) } \\
\hline \multicolumn{6}{|c|}{ Heterogeneity: $\mathrm{Tau}^{2}=0 ; \mathrm{Chi}^{2}=1.37, \mathrm{df}=2(\mathrm{P}=0.5) ; \mathrm{I}^{2}=0 \%$} \\
\hline
\end{tabular}

\section{Analysis 2.2. Comparison 2 Efficacy for acute ischemic stroke, Outcome 2 Functional independence.}

\begin{tabular}{|c|c|c|c|c|c|}
\hline Study or subgroup & $\begin{array}{c}\text { Experimental } \\
n / N \\
\end{array}$ & $\begin{array}{c}\text { Control } \\
\mathrm{n} / \mathrm{N}\end{array}$ & $\begin{array}{c}\text { Risk Ratio } \\
\text { M-H, Random, } 95 \% \mathrm{Cl}\end{array}$ & Weight & $\begin{array}{c}\text { Risk Ratio } \\
\text { M-H, Random, } 95 \% \mathrm{CI}\end{array}$ \\
\hline \multicolumn{6}{|c|}{ 2.2.1 Chlormethiazole versus placebo } \\
\hline Lyden 2001 & $64 / 97$ & $62 / 92$ & & $12.24 \%$ & $0.98[0.8,1.2]$ \\
\hline Lyden 2002 & $246 / 599$ & $268 / 599$ & - & $25.78 \%$ & $0.92[0.81,1.05]$ \\
\hline Wahlgren 1999 & $352 / 631$ & $345 / 628$ & $\bar{\square}$ & $39.22 \%$ & $1.02[0.92,1.12]$ \\
\hline Subtotal $(95 \% \mathrm{Cl})$ & 1327 & 1319 & & $77.25 \%$ & $0.98[0.91,1.05]$ \\
\hline \multicolumn{6}{|c|}{ Heterogeneity: $\operatorname{Tau}^{2}=0 ; \mathrm{Chi}^{2}=1.47, \mathrm{df}=2(\mathrm{P}=0.48) ; \mathrm{I}^{2}=0 \%$} \\
\hline \multicolumn{6}{|c|}{ Test for overall effect: $Z=0.57(P=0.57)$} \\
\hline \multicolumn{6}{|c|}{ 2.2.2 Diazepam versus placebo } \\
\hline Lodder 2006 & $203 / 380$ & $178 / 368$ & $\rightarrow-$ & $22.75 \%$ & $1.1[0.96,1.27]$ \\
\hline Subtotal $(95 \% \mathrm{Cl})$ & 380 & 368 & & $22.75 \%$ & $1.1[0.96,1.27]$ \\
\hline \multicolumn{6}{|c|}{ Heterogeneity: Not applicable } \\
\hline \multicolumn{6}{|c|}{ Test for overall effect: $Z=1.38(P=0.17)$} \\
\hline
\end{tabular}




\begin{tabular}{|c|c|c|c|c|c|}
\hline Study or subgroup & $\begin{array}{c}\text { Experimental } \\
n / N\end{array}$ & $\begin{array}{c}\text { Control } \\
n / N\end{array}$ & $\begin{array}{c}\text { Risk Ratio } \\
\text { M-H, Random, 95\% CI }\end{array}$ & Weight & $\begin{array}{c}\text { Risk Ratio } \\
\text { M-H, Random, } 95 \% \mathrm{Cl}\end{array}$ \\
\hline Total $(95 \% \mathrm{Cl})$ & 1707 & 1687 & & $100 \%$ & $1[0.93,1.08]$ \\
\hline \multicolumn{6}{|c|}{ Total events: 865 (Experimental), 853 (Control) } \\
\hline \multicolumn{6}{|c|}{ Heterogeneity: $\mathrm{Tau}^{2}=0 ; \mathrm{Chi}^{2}=3.67, \mathrm{df}=3(\mathrm{P}=0.3) ; \mathrm{I}^{2}=18.31 \%$} \\
\hline \multicolumn{6}{|c|}{ Test for overall effect: $Z=0.1(P=0.92)$} \\
\hline \multicolumn{6}{|c|}{ Test for subgroup differences: $\mathrm{Chi}^{2}=2.21, \mathrm{df}=1(\mathrm{P}=0.14), \mathrm{I}^{2}=54.75 \%$} \\
\hline
\end{tabular}

\section{Comparison 3. Efficacy for acute hemorrhagic stroke}

\begin{tabular}{|c|c|c|c|c|}
\hline Outcome or subgroup title & No. of studies & $\begin{array}{l}\text { No. of partici- } \\
\text { pants }\end{array}$ & Statistical method & Effect size \\
\hline 1 Death or dependency & 2 & 292 & Risk Ratio (M-H, Random, 95\% Cl) & $0.99[0.75,1.30]$ \\
\hline $\begin{array}{l}1.1 \text { Chlormethiazole versus } \\
\text { placebo }\end{array}$ & 2 & 292 & Risk Ratio (M-H, Random, 95\% Cl) & $0.99[0.75,1.30]$ \\
\hline 2 Functional independence & 3 & 387 & Risk Ratio (M-H, Random, 95\% Cl) & $0.97[0.81,1.16]$ \\
\hline $\begin{array}{l}2.1 \text { Chlormethiazole versus } \\
\text { placebo }\end{array}$ & 2 & 292 & Risk Ratio (M-H, Random, 95\% Cl) & $1.00[0.83,1.21]$ \\
\hline 2.2 Diazepam versus placebo & 1 & 95 & Risk Ratio (M-H, Random, 95\% Cl) & $0.80[0.50,1.27]$ \\
\hline
\end{tabular}

Analysis 3.1. Comparison 3 Efficacy for acute hemorrhagic stroke, Outcome 1 Death or dependency.

\begin{tabular}{|c|c|c|c|c|c|}
\hline Study or subgroup & $\begin{array}{c}\text { Experimental } \\
\mathrm{n} / \mathrm{N} \\
\end{array}$ & $\begin{array}{c}\text { Control } \\
\mathrm{n} / \mathrm{N}\end{array}$ & $\begin{array}{c}\text { Risk Ratio } \\
\text { M-H, Random, 95\% CI }\end{array}$ & Weight & $\begin{array}{c}\text { Risk Ratio } \\
\text { M-H, Random, } 95 \% \mathrm{CI}\end{array}$ \\
\hline \multicolumn{6}{|c|}{ 3.1.1 Chlormethiazole versus placebo } \\
\hline Lyden 2000 & $39 / 96$ & $39 / 102$ & - & $64.13 \%$ & $1.06[0.75,1.5]$ \\
\hline Wahlgren 1999 & $19 / 47$ & $22 / 47$ & & $35.87 \%$ & $0.86[0.54,1.37]$ \\
\hline Subtotal $(95 \% \mathrm{CI})$ & 143 & 149 & & $100 \%$ & $0.99[0.75,1.3]$ \\
\hline \multicolumn{6}{|c|}{ Total events: 58 (Experimental), 61 (Control) } \\
\hline \multicolumn{6}{|c|}{ Test for overall effect: $Z=0.1(P=0.92)$} \\
\hline Total $(95 \% \mathrm{Cl})$ & 143 & 149 & & $100 \%$ & $0.99[0.75,1.3]$ \\
\hline \multicolumn{6}{|c|}{ Total events: 58 (Experimental), 61 (Control) } \\
\hline \multicolumn{6}{|c|}{ Heterogeneity: $\mathrm{Tau}^{2}=0 ; \mathrm{Chi}^{2}=0.5, \mathrm{df}=1(\mathrm{P}=0.48) ; \mathrm{I}^{2}=0 \%$} \\
\hline \multicolumn{6}{|c|}{ Test for overall effect: $Z=0.1(P=0.92)$} \\
\hline
\end{tabular}


Analysis 3.2. Comparison 3 Efficacy for acute hemorrhagic stroke, Outcome 2 Functional independence.

\begin{tabular}{|c|c|c|c|c|c|}
\hline Study or subgroup & $\begin{array}{c}\text { Experimental } \\
n / N\end{array}$ & $\begin{array}{c}\text { Control } \\
n / N\end{array}$ & $\begin{array}{c}\text { Risk Ratio } \\
\text { M-H, Random, } 95 \% \mathrm{Cl}\end{array}$ & Weight & $\begin{array}{c}\text { Risk Ratio } \\
\text { M-H, Random, } 95 \% \mathrm{Cl}\end{array}$ \\
\hline \multicolumn{6}{|c|}{ 3.2.1 Chlormethiazole versus placebo } \\
\hline Lyden 2000 & $57 / 96$ & $63 / 102$ & & $61.07 \%$ & $0.96[0.77,1.2]$ \\
\hline Wahlgren 1999 & $28 / 47$ & $25 / 47$ & & $24.3 \%$ & $1.12[0.78,1.6]$ \\
\hline Subtotal (95\% CI) & 143 & 149 & & $85.37 \%$ & $1[0.83,1.21]$ \\
\hline \multicolumn{6}{|c|}{ Total events: 85 (Experimental), 88 (Control) } \\
\hline \multicolumn{6}{|c|}{ Test for overall effect: $\mathrm{Z}=0.04(\mathrm{P}=0.97)$} \\
\hline \multicolumn{6}{|c|}{ 3.2.2 Diazepam versus placebo } \\
\hline Lodder 2006 & $18 / 46$ & $24 / 49$ & & $14.63 \%$ & $0.8[0.5,1.27]$ \\
\hline Subtotal $(95 \% \mathrm{Cl})$ & 46 & 49 & & $14.63 \%$ & $0.8[0.5,1.27]$ \\
\hline \multicolumn{6}{|c|}{ Total events: 18 (Experimental), 24 (Control) } \\
\hline \multicolumn{6}{|c|}{ Test for overall effect: $\mathrm{Z}=0.96(\mathrm{P}=0.34)$} \\
\hline Total $(95 \% \mathrm{Cl})$ & 189 & 198 & & $100 \%$ & $0.97[0.81,1.16]$ \\
\hline \multicolumn{6}{|c|}{ Total events: 103 (Experimental), 112 (Control) } \\
\hline \multicolumn{6}{|c|}{ Heterogeneity: $\operatorname{Tau}^{2}=0 ; \mathrm{Chi}^{2}=1.32, \mathrm{df}=2(\mathrm{P}=0.52) ; \mathrm{I}^{2}=0 \%$} \\
\hline \multicolumn{6}{|c|}{ Test for overall effect: $Z=0.33(P=0.74)$} \\
\hline Test for subgroup dif & $.81, \mathrm{df}=1(\mathrm{P}=0.37)$, & & & & \\
\hline
\end{tabular}

\section{Comparison 4. Efficacy for TACS}

\begin{tabular}{lllll}
\hline Outcome or subgroup title & No. of studies & $\begin{array}{l}\text { No. of partici- } \\
\text { pants }\end{array}$ & Statistical method & Effect size \\
\hline $\begin{array}{lllll}\text { Functional independence } \\
\text { 1.1 Chlormethiazole versus place- }\end{array}$ & 2 & 635 & Risk Ratio (M-H, Random, 95\% Cl) & $1.33[1.08,1.63]$ \\
\hline \begin{tabular}{l} 
bo \\
\hline
\end{tabular} & 635 & Risk Ratio (M-H, Random, 95\% Cl) & $1.33[1.08,1.63]$ \\
\end{tabular}

Analysis 4.1. Comparison 4 Efficacy for TACS, Outcome 1 Functional independence.

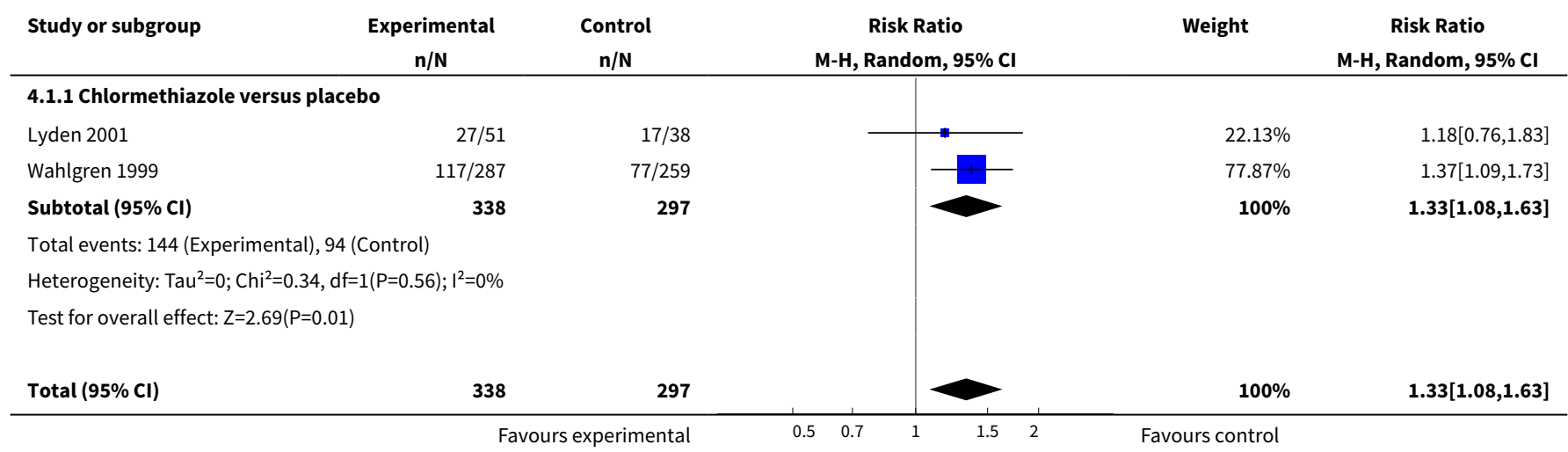




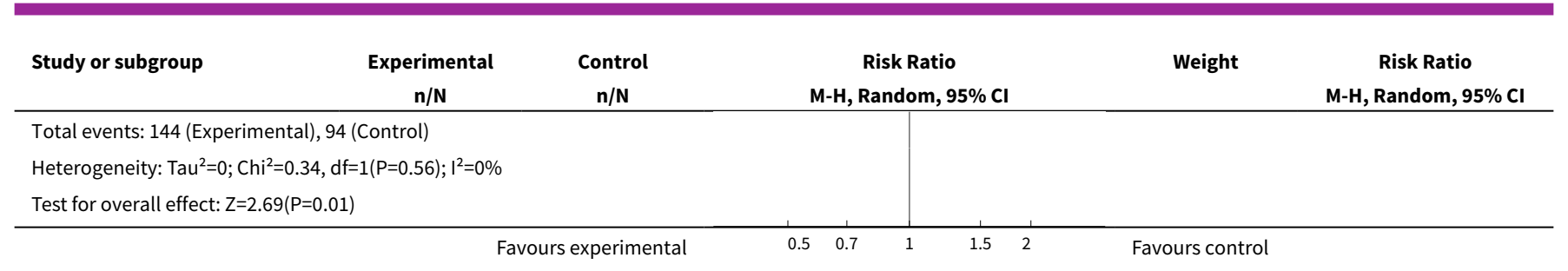

\section{Comparison 5. Efficacy for early-treated acute stroke}

\begin{tabular}{|c|c|c|c|c|}
\hline Outcome or subgroup title & No. of studies & $\begin{array}{l}\text { No. of partici- } \\
\text { pants }\end{array}$ & Statistical method & Effect size \\
\hline 1 Functional independence & 3 & 1314 & $\begin{array}{l}\text { Risk Ratio (M-H, Random, 95\% } \\
\mathrm{Cl} \text { ) }\end{array}$ & $0.99[0.80,1.21]$ \\
\hline $\begin{array}{l}1.1 \text { Chlormethiazole versus placebo } \\
\text { ( }<6 \text { hours) }\end{array}$ & 2 & 1182 & $\begin{array}{l}\text { Risk Ratio (M-H, Random, 95\% } \\
\mathrm{Cl})\end{array}$ & $0.93[0.73,1.19]$ \\
\hline $\begin{array}{l}1.2 \text { Diazepam versus placebo }(<3 \\
\text { hours) }\end{array}$ & 1 & 132 & $\begin{array}{l}\text { Risk Ratio (M-H, Random, 95\% } \\
\mathrm{Cl})\end{array}$ & $1.21[0.85,1.74]$ \\
\hline
\end{tabular}

Analysis 5.1. Comparison 5 Efficacy for early-treated acute stroke, Outcome 1 Functional independence.

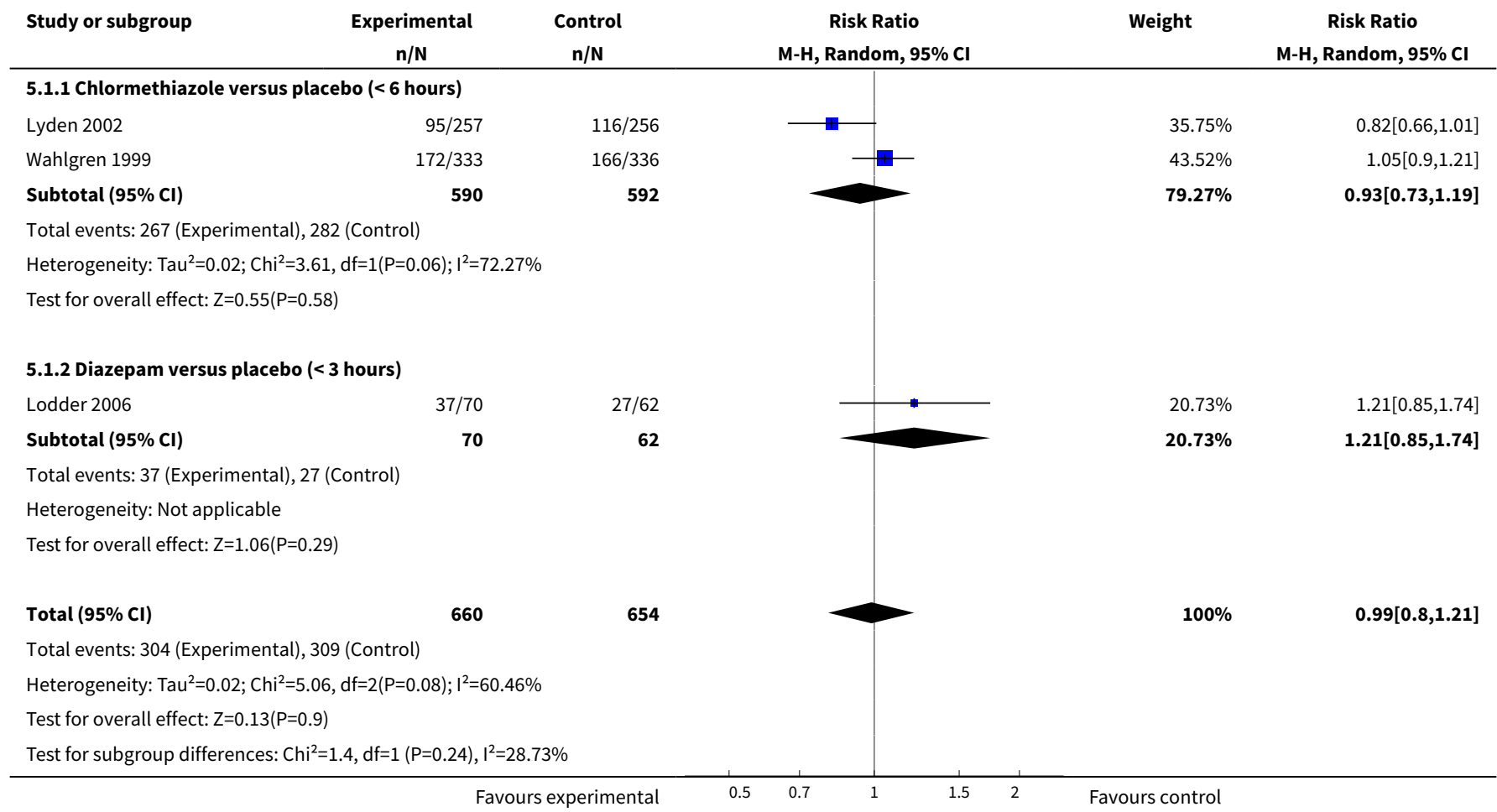




\section{AP P E N DICES}

\section{Appendix 1. Cochrane Central Register of Controlled Trials (CENTRAL)}

\#1 MeSH descriptor: [Basal Ganglia Cerebrovascular Disease]

\#2 MeSH descriptor: [Brain Ischemia]

\#3 MeSH descriptor: [Carotid Artery Diseases]

\#4 MeSH descriptor: [Cerebrovascular Trauma]

\#5 MeSH descriptor: [Intracranial Arterial Diseases]

\#6 MeSH descriptor: [Intracranial Arteriovenous Malformations]

\#7 MeSH descriptor: [Intracranial Embolism and Thrombosis]

\#8 MeSH descriptor: [Intracranial Hemorrhages]

\#9 MeSH descriptor: [Stroke] explode all trees

\#10 MeSH descriptor: [Brain Infarction]

\#11 MeSH descriptor: [Vasospasm, Intracranial] explode all trees

\#12 MeSH descriptor: [Cerebrovascular Disorders] explode all trees

\#13 (stroke or poststroke or "post-stroke" or cerebrovasc* or brain next vasc* or cerebral next vasc* or cva* or apoplex* or SAH):ti,ab,kw \#14 ((brain* or cerebr ${ }^{\star}$ or cerebell* or intracran* or intracerebral) near/5 (isch* mi $^{\star}$ or infarct* or thrombo* or emboli* or occlus $\left.{ }^{\star}\right)$ ):ti,ab,kw \#15 ((brain* or cerebr* or cerebell* or intracerebral or intracranial or subarachnoid) near/5 (haemorrhage* or hemorrhage* or haematoma* or hematoma* or bleed $\left.{ }^{\star}\right)$ )

$\# 16\{$ or \#1-\#15\}

\#17 MeSH descriptor: [GABA Agonists] explode all trees

\#18 MeSH descriptor: [GABA-A Receptor Antagonists]

\#19 MeSH descriptor: [GABA-B Receptor Agonists]

\#20 MeSH descriptor: [GABA Modulators] explode all trees

\#21 MeSH descriptor: [gamma-Aminobutyric Acid]

\#22 MeSH descriptor: [Receptors, GABA]

\#23 (("gamma aminobutyric acid" or "gamma-aminobutyric acid" or gaba or "gaba-A" or "gaba-B") near/5 (agonist* or modulator* or stimulat* or stimulant $\left.\left.{ }^{\star}\right)\right): t i, a b, k w$

\#24 ((gabaergic or "gaba-ergic" or gabamimetic) near/5 (agent* or drug* or stimul*)):ti,ab,kw

\#25 (Adipiplon or Alprazolam or Amobarbital or Arbaclofen or Atagabalin or AZD3355 or AZD9343 or Baclofen or Barbital or Benzodiazepine* or Bromazepam or Chlordiazepoxide or Chlormethiazole or Clomethiazole or Clonazepam or Clorazepate or Dipotassium or Diazepam or Dihydromuscimol or Estazolam or Fengabine or Flumazenil or Flunitrazepam or Flurazepam or Gabapentin or Gaboxadol or Hexobarbital or "Hopantenate calcium" or Lesogaberan or Lorazepam or Medazepam or Mephobarbital or Midazolam or muscimol or Nitrazepam or Nordazepam or Oxazepam or "Oxybate sodium" or Pagoclone or Pentobarbital or Phenobarbital or Picamilon or Prazepam or Pregabalin or Progabide or Secobarbital or Temazepam or Thiamylal or Thiopental or THIP or TPA023 or Triazolam or "Valproic acid" or Vigabatrin or Zolazepam or XP19986):ti,ab,kw

\#26 \{or \#17-\#25\}

\#27 \#16 and \#26 


\section{Appendix 2. MEDLINE (Ovid) search strategy}

1. cerebrovascular disorders/ or exp basal ganglia cerebrovascular disease/ or exp brain ischemia/ or exp carotid artery diseases/ or exp cerebrovascular trauma/ or exp intracranial arterial diseases/ or exp intracranial arteriovenous malformations/ or exp "intracranial embolism and thrombosis"/ or exp intracranial hemorrhages/or stroke/ or exp brain infarction/ or vasospasm, intracranial/

2. (stroke or poststroke or post-stroke or cerebrovasc\$ or brain vasc\$ or cerebral vasc\$ or cva\$ or apoplex\$ or SAH).tw.

3. ((brain\$ or cerebr\$ or cerebell\$ or intracran\$ or intracerebral) adj5 (isch?emi\$ or infarct\$ or thrombo $\$$ or emboli\$ or occlus\$)).tw.

4. ((brain\$ or cerebr\$ or cerebell\$ or intracerebral or intracranial or subarachnoid) adj5 (haemorrhage\$ or hemorrhage\$ or haematoma\$ or hematoma\$ or bleed\$)).tw.

5. ((transi\$ adj3 isch?em\$ adj3 attack\$) or TIA\$1).tw.

6. 1 or 2 or 3 or 4 or 5

7. gaba agonists/ or exp gaba-a receptor agonists/ or exp gaba-b receptor agonists/ or exp gaba modulators/

8. exp gamma-Aminobutyric Acid/tu [Therapeutic Use]

9. exp Receptors, GABA/de [Drug Effects]

10. ((gamma aminobutyric acid or gamma-aminobutyric acid or gaba or gaba-A or gaba-B) adj5 (agonist\$ or modulator\$ or stimulat\$ or stimulant\$)).tw.

11. ((gabaergic or gaba-ergic or gabamimetic) adj5 (agent\$ or drug\$ or stimul\$)).tw.

12. (Adipiplon or Alprazolam or Amobarbital or Arbaclofen or Atagabalin or AZD3355 or AZD9343 or Baclofen or Barbital or Benzodiazepine \$ or Bromazepam or Chlordiazepoxide or Chlormethiazole or Clomethiazole or Clonazepam or Clorazepate or Dipotassium or Diazepam or Dihydromuscimol or Estazolam or Fengabine or Flumazenil or Flunitrazepam or Flurazepam or Gabapentin or Gaboxadol or Hexobarbital or Hopantenate calcium or Lesogaberan or Lorazepam or Medazepam or Mephobarbital or Midazolam or muscimol or Nitrazepam or Nordazepam or Oxazepam or Oxybate sodium or Pagoclone or Pentobarbital or Phenobarbital or Picamilon or Prazepam or Pregabalin or Progabide or Secobarbital or Temazepam or Thiamylal or Thiopental or THIP or TPA023 or Triazolam or Valproic acid or Vigabatrin or Zolazepam or XP19986).tw,nm.

13. 7 or 8 or 9 or 10 or 11 or 12

14. Randomized Controlled Trials as Topic/

15. Random Allocation/

16. Controlled Clinical Trials as Topic/

17. control groups/

18. clinical trials as topic/ or clinical trials, phase i as topic/ or clinical trials, phase ii as topic/ or clinical trials, phase iii as topic/ or clinical trials, phase iv as topic/

19. double-blind method/

20. single-blind method/

21. Placebos/

22. placebo effect/

23. Drug Evaluation/

24. Research Design/

25. randomized controlled trial.pt.

26. controlled clinical trial.pt.

27. (clinical trial or clinical trial phase i or clinical trial phase ii or clinical trial phase iii or clinical trial phase iv).pt.

28. (random\$ or RCT or RCTs).tw. 
29. (controlled adj5 (trial\$ or stud\$)).tw.

30. (clinical\$ adj5 trial\$).tw.

31. ((control or treatment or experiment\$ or intervention) adj5 (group\$ or subject\$ or patient\$)).tw.

32. (quasi-random $\$$ or quasi random $\$$ or pseudo-random $\$$ or pseud or random $\$$ ).tw.

33. ((singl\$ or doubl\$ or tripl\$ or trebl\$) adj5 (blind\$ or mask\$)).tw.

34. placebo\$.tw.

35. controls.tw.

36. exp animals/ not humans.sh.

37.14 or 15 or 16 or 17 or 18 or 19 or 20 or 21 or 22 or 23 or 24 or 25 or 26 or 27 or 28 or 29 or 30 or 31 or 32 or 33 or 34 or 35

38. 6 and 13 and 37

39. 38 not 36

40. limit 39 to $y r=" 2013$-Current"

\section{Appendix 3. Embase (Ovid) search strategy}

1. cerebrovascular disease/ or exp basal ganglion hemorrhage/ or exp brain hematoma/ or exp brain hemorrhage/ or exp brain infarction/or exp brain ischemia/ or exp carotid artery disease/ or cerebral artery disease/or exp cerebrovascular accident/ or exp intracranial aneurysm/ or exp occlusive cerebrovascular disease/ or vertebrobasilar insufficiency/ or stroke/ or stroke patient/ or stroke unit/

2. (stroke or poststroke or post-stroke or cerebrovasc\$ or brain vasc\$ or cerebral vasc\$ or cva\$ or apoplex\$ or SAH).tw.

3. ((brain\$ or cerebr\$ or cerebell\$ or intracran\$ or intracerebral) adj5 (isch?emi\$ or infarct\$ or thrombo $\$$ or emboli\$ or occlus\$)).tw.

4. ((brain\$ or cerebr\$ or cerebell\$ or intracerebral or intracranial or subarachnoid) adj5 (haemorrhage\$ or hemorrhage\$ or haematoma\$ or hematoma\$ or bleed\$)).tw.

5.1 or 2 or 3 or 4

6. exp 4 aminobutyric acid receptor stimulating agent/

7. 4 aminobutyric acid/ct, ad, dt or exp 4 aminobutyric acid receptor/ct, dt

8. ((gamma aminobutyric acid or gamma-aminobutyric acid or gaba or gaba-A or gaba-B) adj5 (agonist\$ or modulator\$ or stimul\$)).tw.

9. ((gabaergic or gaba-ergic or gabamimetic) adj5 (agent\$ or drug\$ or stimul\$)).tw.

10. (Adipiplon or Alprazolam or Amobarbital or Arbaclofen or Atagabalin or AZD3355 or AZD9343 or Baclofen or Barbital or Benzodiazepine \$ or Bromazepam or Chlordiazepoxide or Chlormethiazole or Clomethiazole or Clonazepam or Clorazepate or Dipotassium or Diazepam or Dihydromuscimol or Estazolam or Fengabine or Flumazenil or Flunitrazepam or Flurazepam or Gabapentin or Gaboxadol or Hexobarbital or Hopantenate calcium or Lesogaberan or Lorazepam or Medazepam or Mephobarbital or Midazolam or muscimol or Nitrazepam or Nordazepam or Oxazepam or Oxybate sodium or Pagoclone or Pentobarbital or Phenobarbital or Picamilon or Prazepam or Pregabalin or Progabide or Secobarbital or Temazepam or Thiamylal or Thiopental or THIP or TPA023 or Triazolam or Valproic acid or Vigabatrin or Zolazepam or XP19986).tw.

11.6 or 7 or 8 or 9 or 10

12.5 and 11

13. Randomized Controlled Trial/ or Randomization/

14. Controlled Study/

15. control group/

16. clinical trial/ or phase 1 clinical trial/ or phase 2 clinical trial/ or phase 3 clinical trial/ or phase 4 clinical trial/ or controlled clinical trial/ 17. Double Blind Procedure/ 
18. Single Blind Procedure/ or triple blind procedure/

19. placebo/

20. "types of study"/

21. trial.ti.

22. (random\$ or RCT or RCTs).tw.

23. (controlled adj5 (trial\$ or stud\$)).tw.

24. (clinical\$ adj5 trial\$).tw.

25. ((control or treatment or experiment\$ or intervention) adj5 (group\$ or subject\$ or patient\$)).tw.

26. (quasi-random\$ or quasi random\$ or pseudo-random\$ or pseudo random\$).tw.

27. ((singl\$ or doubl\$ or tripl\$ or trebl\$) adj5 (blind\$ or mask\$)).tw.

28. placebo\$.tw.

29. controls.tw.

30. or $/ 13-29$

31. 12 and 30

32. (exp animals/or exp invertebrate/ or animal experiment/ or animal model/or animal tissue/ or animal cell/ or nonhuman/) not (human/ or normal human/ or human cell/)

33. 31 not 32

34. limit 33 to $y r=" 2013$-Current"

\section{Appendix 4. CINAHL (EBSCO) search strategy}

S1. (MH "Cerebrovascular Disorders") OR (MH "Basal Ganglia Cerebrovascular Disease+") OR (MH "Carotid Artery Diseases+") OR (MH "Cerebral Ischemia+") OR (MH "Cerebral Vasospasm") OR (MH "Intracranial Arterial Diseases+") OR (MH "Intracranial Embolism and Thrombosis") OR (MH "Intracranial Hemorrhage+") OR (MH "Stroke") OR (MH "Vertebral Artery Dissections")

S2. (MH "Stroke Patients") OR (MH "Stroke Units")

S3. TI ( stroke or poststroke or post-stroke or cerebrovasc* or brain vasc ${ }^{\star}$ or cerebral vasc or cva or apoplex or SAH ) or AB ( stroke or poststroke or post-stroke or cerebrovasc* or brain vasc* or cerebral vasc or cva or apoplex or SAH )

S4. TI ( brain* or cerebr ${ }^{\star}$ or cerebell ${ }^{\star}$ or intracran* or intracerebral ) or AB ( brain* or cerebr $^{\star}$ or cerebell ${ }^{\star}$ or intracran $^{\star}$ or intracerebral)

S5. TI ( ischemi ${ }^{\star}$ or ischaemi ${ }^{\star}$ or infarct ${ }^{\star}$ or thrombo ${ }^{\star}$ or emboli* or occlus ${ }^{\star}$ ) or AB (ischemi ${ }^{\star}$ or ischaemi or infarct $^{\star}$ or thrombo $^{\star}$ or emboli ${ }^{\star}$ or occlus*)

S6. S4 and S5

S7. TI ( brain* or cerebr ${ }^{\star}$ or cerebell* or intracerebral or intracranial or subarachnoid ) or AB ( brain* or cerebr ${ }^{\star}$ or cerebell* or intracerebral or intracranial or subarachnoid)

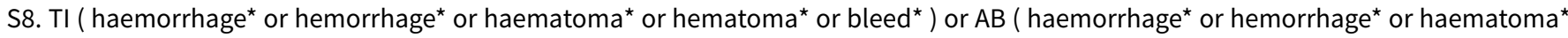
or hematoma* or bleed*)

S9. S7 and S8

S10. S1 OR S2 OR S3 OR S6 OR S9

S11. (MH "GABA Agonists+") or (MH "GABA Modulators+")

S12. (MH "GABA/TU") 
S13. TI (gamma aminobutyric acid or gamma-aminobutyric acid or gaba or gaba-A or gaba-B) or AB (gamma aminobutyric acid or gammaaminobutyric acid or gaba or gaba-A or gaba-B)

S14. TI (agonist* or modulator ${ }^{\star}$ or stimulat ${ }^{\star}$ or stimulant ${ }^{\star}$ ) or AB (agonist ${ }^{\star}$ or modulator ${ }^{\star}$ or stimulat ${ }^{\star}$ or stimulant $^{\star}$ )

S15. S13 and S14

S16. TI (gabaergic or gaba-ergic or gabamimetic) or AB (gabaergic or gaba-ergic or gabamimetic)

S17. TI (agent* or drug* or stimul*) or AB (agent* or drug* or stimul*)

S18. S16 and S17

S19. TI (Adipiplon or Alprazolam or Amobarbital or Arbaclofen or Atagabalin or AZD3355 or AZD9343 or Baclofen or Barbital or Benzodiazepine\$ or Bromazepam or Chlordiazepoxide or Chlormethiazole or Clomethiazole or Clonazepam or Clorazepate or Dipotassium or Diazepam or Dihydromuscimol or Estazolam or Fengabine or Flumazenil or Flunitrazepam or Flurazepam or Gabapentin or Gaboxadol or Hexobarbital or Hopantenate calcium or Lesogaberan or Lorazepam or Medazepam or Mephobarbital or Midazolam or muscimol or Nitrazepam or Nordazepam or Oxazepam or Oxybate sodium or Pagoclone or Pentobarbital or Phenobarbital or Picamilon or Prazepam or Pregabalin or Progabide or Secobarbital or Temazepam or Thiamylal or Thiopental or THIP or TPA023 or Triazolam or Valproic acid or Vigabatrin or Zolazepam or XP19986) or AB (Adipiplon or Alprazolam or Amobarbital or Arbaclofen or Atagabalin or AZD3355 or AZD9343 or Baclofen or Barbital or Benzodiazepine\$ or Bromazepam or Chlordiazepoxide or Chlormethiazole or Clomethiazole or Clonazepam or Clorazepate or Dipotassium or Diazepam or Dihydromuscimol or Estazolam or Fengabine or Flumazenil or Flunitrazepam or Flurazepam or Gabapentin or Gaboxadol or Hexobarbital or Hopantenate calcium or Lesogaberan or Lorazepam or Medazepam or Mephobarbital or Midazolam or muscimol or Nitrazepam or Nordazepam or Oxazepam or Oxybate sodium or Pagoclone or Pentobarbital or Phenobarbital or Picamilon or Prazepam or Pregabalin or Progabide or Secobarbital or Temazepam or Thiamylal or Thiopental or THIP or TPA023 or Triazolam or Valproic acid or Vigabatrin or Zolazepam or XP19986)

\section{S20. S11 OR S12 or S15 or S18 or S19}

\section{S21. S10 AND S20}

\section{Appendix 5. AMED (Ovid) search strategy}

1. cerebrovascular disorders/or cerebral hemorrhage/ or cerebral infarction/or cerebral ischemia/ or cerebrovascular accident/ or stroke/

2. (stroke or poststroke or post-stroke or cerebrovasc\$ or brain vasc\$ or cerebral vasc\$ or cva\$ or apoplex\$ or SAH).tw.

3. ((brain\$ or cerebr\$ or cerebell\$ or intracran\$ or intracerebral) adj5 (isch?emi\$ or infarct\$ or thrombo or emboli\$ or occlus\$)).tw.

4. ((brain\$ or cerebr\$ or cerebell\$ or intracerebral or intracranial or subarachnoid) adj5 (haemorrhage\$ or hemorrhage\$ or haematoma\$ or hematoma\$ or bleed\$)).tw.

\section{1 or 2 or 3 or 4}

6. ((gamma aminobutyric acid or gamma-aminobutyric acid or gaba or gaba-A or gaba-B) adj5 (agonist\$ or modulator\$ or stimulat\$ or stimulant\$)).tw.

7. ((gabaergic or gaba-ergic or gabamimetic) adj5 (agent\$ or drug\$ or stimul\$)).tw.

8. (Adipiplon or Alprazolam or Amobarbital or Arbaclofen or Atagabalin or AZD3355 or AZD9343 or Baclofen or Barbital or Benzodiazepine\$ or Bromazepam or Chlordiazepoxide or Chlormethiazole or Clomethiazole or Clonazepam or Clorazepate or Dipotassium or Diazepam or Dihydromuscimol or Estazolam or Fengabine or Flumazenil or Flunitrazepam or Flurazepam or Gabapentin or Gaboxadol or Hexobarbital or Hopantenate calcium or Lesogaberan or Lorazepam or Medazepam or Mephobarbital or Midazolam or muscimol or Nitrazepam or Nordazepam or Oxazepam or Oxybate sodium or Pagoclone or Pentobarbital or Phenobarbital or Picamilon or Prazepam or Pregabalin or Progabide or Secobarbital or Temazepam or Thiamylal or Thiopental or THIP or TPA023 or Triazolam or Valproic acid or Vigabatrin or Zolazepam or XP19986).tw.

\section{6 or 7 or 8}

10.5 and 9

11. limit 10 to $y r=" 2013$-Current"

Appendix 6. Chinese databases search strategy

1. 脑卒中 $O R$ 脑血管病 $O R$ 缺血性卒中 $O R$ 脑梗塞 $O R$ 脑梗死 $O R$ 出血性卒中 $O R$ 脑出血 
2. 主题词="脑梗死" [不加权: 扩展] OR "脑血管障碍" [不加权: 扩展] OR "脑出血" [不加权: 扩展 ]

3. 中风 OR CVD OR 脑血管意外

4. $\gamma$-氨基丁酸受体激动剂 $O R$ GABA受体激动剂 $O R$ 氯美噻唑 $O R$ 地西泮

5. (\#3) OR (\#2) OR (\#1)

6. (\#5) AND (\#4) AND (临床试验[文献类型] OR 随机对照试验[文献类型])

\section{Appendix 7. Trials registers search strategy}

1. "Stroke" AND "Gamma aminobutyric acid receptor agonists" (“脑卒中”, " $\mathrm{Y}$-氨基丁酸受体激动剂")

2. "Stroke" AND "GABA receptor agonists" (“脑卒中”, "GABA受体激动剂")

3. "Stroke" AND "Chlormethiazole" (“脑卒中”, "氯美噻唑")

4. "Stroke" AND "Diazepam" (“脑卒中”, "地西泮")

WHAT'S NEW

\begin{tabular}{lll}
\hline Date & Event & Description \\
\hline 22 May 2018 & New search has been performed & $\begin{array}{l}\text { We updated all the searches for this review to May 2018 but did } \\
\text { not identify any new information for inclusion. Therefore, the } \\
\text { conclusions of the review remain unchanged. }\end{array}$ \\
\hline 22 May 2018 & $\begin{array}{l}\text { New citation required but conclusions } \\
\text { have not changed }\end{array}$ & Conclusions not changed. \\
\hline
\end{tabular}

\section{CONTRIBUTIONS OFAUTHORS}

Jia Liu and Lu-Ning Wang formulated the idea for the review and developed the basis for the review. Jia Liu, Lu-Ning Wang and Jing Zhang took the primary role in searching, identifying and assessing studies; extracting and analyzing the data; and writing up the full review. Jia Liu supervised the quality of the methodology and statistics used. The manuscript was written by Jia Liu and Jing Zhang, and revised by Lu-Ning Wang. Jia Liu will be responsible for updating the review.

\section{DECLARATIONS OF INTEREST}

Jia Liu: none known.

Jing Zhang: none known.

Lu-Ning Wang: none known.

\section{SOURCES OF SUPPORT}

\section{Internal sources}

- None, Other.

\section{External sources}

- None, Other.

\section{DIFFERENCES BETWEEN PROTOCOLANDREVIEW}

We added the number of people with frequent adverse events as a primary outcome, which was not included in the protocol. 


\section{N D EX TERMS}

\section{Medical Subject Headings (MeSH)}

Acute Disease; Chlormethiazole [adverse effects] ["therapeutic use]; Diazepam [adverse effects] [ ${ }^{*}$ therapeutic use]; Disorders of Excessive Somnolence [chemically induced]; GABA Agonists [adverse effects] [ ${ }^{\star}$ therapeutic use]; Neuroprotective Agents [adverse effects] [`therapeutic use]; Randomized Controlled Trials as Topic; Rhinitis [chemically induced]; Stroke [ ${ }^{\star} d r u g$ therapy] [mortality]; gamma-Aminobutyric Acid [*therapeutic use]

\section{MeSH check words}

Humans 